IZA DP No. 8121

Unemployment Transitions to Stable and Unstable Jobs Before and During the Crisis

Amparo Nagore García

Arthur van Soest

April 2014 


\title{
Unemployment Transitions to Stable and Unstable Jobs Before and During the Crisis
}

\author{
Amparo Nagore García \\ University of Valencia \\ Arthur van Soest \\ Tilburg University \\ and IZA
}

\section{Discussion Paper No. 8121 \\ April 2014}

\author{
IZA \\ P.O. Box 7240 \\ 53072 Bonn \\ Germany \\ Phone: +49-228-3894-0 \\ Fax: +49-228-3894-180 \\ E-mail: iza@iza.org
}

\begin{abstract}
Any opinions expressed here are those of the author(s) and not those of IZA. Research published in this series may include views on policy, but the institute itself takes no institutional policy positions. The IZA research network is committed to the IZA Guiding Principles of Research Integrity.

The Institute for the Study of Labor (IZA) in Bonn is a local and virtual international research center and a place of communication between science, politics and business. IZA is an independent nonprofit organization supported by Deutsche Post Foundation. The center is associated with the University of Bonn and offers a stimulating research environment through its international network, workshops and conferences, data service, project support, research visits and doctoral program. IZA engages in (i) original and internationally competitive research in all fields of labor economics, (ii) development of policy concepts, and (iii) dissemination of research results and concepts to the interested public.
\end{abstract}

IZA Discussion Papers often represent preliminary work and are circulated to encourage discussion. Citation of such a paper should account for its provisional character. A revised version may be available directly from the author. 


\title{
ABSTRACT
}

\section{Unemployment Transitions to Stable and Unstable Jobs Before and During the Crisis}

\begin{abstract}
Using administrative records data from Spanish Social Security, we analyse the pattern and the determinants of individual unemployment benefit spell durations. We compare a period of expansion (2005-2007) and the recent recession (2009-2011), allowing us to determine the impact of the current crisis. In line with the duality that characterizes the Spanish labour market, we distinguish between exits to a stable job and exits to an unstable job. We estimate a Multivariate Mixed Proportional Hazard Model for each time period. We find similar effects of the crisis for stable and unstable jobs, which are particularly strong in the first year of the spell. Moreover, slight negative duration dependence is found, especially for stable jobs in the expansion period until the time of unemployment benefit expires. Individuals who are most affected by the financial crisis tend to be males, those aged 16-24 and 40-51 years, those living in regions with higher unemployment rates, individuals who are less qualified or work in manual occupations (particularly construction) and immigrants.
\end{abstract}

JEL Classification: J64, C41, E32

Keywords: unemployment durations, business cycle, dual labour markets, re-employment probability

Corresponding author:

Amparo Nagore García

Department of Applied Economics

University of Valencia

Avda. de los Naranjos s/n

46022 Valencia

Spain

E-mail: amparo.nagore@uv.es

\footnotetext{
" The authors wish to thank the Spanish Social Security for providing the data for this research and conference participants in Madrid and seminar participants in Tilburg and Valencia for useful comments.
} 


\section{Introduction}

The current economic recession in Spain has led to important adjustments in the labour market, with a reduction of working hours and the dismissal of many workers. The case of Spain is particularly dramatic compared to many other countries that suffered from the crisis. According to the Spanish Labour Force Survey (SLFS), the Spanish unemployment rate has increased from $8.5 \%$ in 2006 to $25 \%$ in 2012. Young workers are specially affected, with the youth unemployment rate reaching $55 \%$ by the end of 2012. The increase in the long-term unemployment rate is also specifically worrying. It has moved from $2 \%$ in 2006 to $14 \%$ by the end of 2012. Long-term unemployment implies a loss of human capital, which reduces the chances of re-employment and increases the risk of social exclusion and loss of welfare. Unemployment also has important consequences for Social Security sustainability, reducing social security contributions and increasing the amount of social benefits to be paid.

In order to understand the unemployment rate it is important to consider both entry into and exit out of unemployment. In this study we focus on exits from unemployment benefit spells via finding a job, since the re-employment probability determines the duration of unemployment benefit spells. Micro-economic studies on how changes in the business cycle affect re-employment probabilities mainly analyse the determinants of the length of individual unemployment spells. Most of these studies consider single spells of unemployment, often spells with unemployment benefits, and the analysis is often focused on a selected group of individuals such as young men. Such studies usually control for the business cycle by including the current local unemployment rate as an explanatory variable (see van den Berg, 2001, for a review). Arulampalam and Stewart (1995) look at the impact of the business cycle in a comparative analysis at two very different points in time using two inflow cohorts. Imbens and Lynch (2006) use multi-spell data for a longitudinal survey of individuals in the US and incorporate seasonal and business cycle effects.

Job search theory gives an ambiguous prediction of the relationship between the business cycle and the duration of unemployment. Increases in unemployment will reduce the reservation wage but also the probability of receiving a job offer. Lynch (1989) and Dynarski and Sheffrin (1990) found that higher unemployment results in lower re-employment probabilities. On the other hand, the models of Meyer (1990) and Solon (1985) suggest that the average duration of unemployment falls in a recession.

The Spanish labour market is characterized by strong duality: There is an important gap between an insider group of workers with stable permanent ('primary') jobs and an outsider group of workers with unstable non-permanent ('secondary') jobs, with poorer working conditions and lower dismissals costs (Alba, 1998; Bentolila and Dolado, 1994; García-Pérez and Muñoz-Bullón, 2011). This duality started with the 1984 reform, which introduced flexibility in hiring through fixed-term contracts without modifying the regulation of secure permanent employment (Bentolila and Dolado, 1994).

Traditionally, labour market duality has been identified with the type of contract - either permanent or fixed-term. Indeed, Bover and Gómez (2004) investigate the determinants of exit rates 
from unemployment to permanent and temporary jobs and find important differences between the two exit patterns. Arranz et al. (2010) use a competing risk model to analyse the exit from unemployment to permanent jobs, temporary jobs, self-employment and inactivity. This distinction, however, may not be so informative anymore in the Spanish context. On the one hand, recent regulations, particularly related to bonuses in Social Security quotas to promote permanent contracts are undermining the concept of a permanent contract. Toharia and Cebrian (2007) show that $41 \%$ of new permanent contracts in 2004 had already ended by October 1, 2005. García-Serrano (2004) found that firms use temporary contracts to reduce production costs of permanent activities.

Although the distinction between temporary and permanent contracts seems to have lost economic meaning, there are still reasons to expect important differences between jobs that last only a short period and jobs that ex post appear to be permanent. Boockmann and Steffes (2005), using German data, have found segmentation within companies based on job duration, with lower qualified workers having significantly shorter durations. Toharia and Malo (2009) argue that large firms in Spain tend to segment workers depending on the employee's productivity. Working conditions tend to be better for more productive workers and firms try to retain this kind of workers. Moreover, productivity and job duration are positively correlated.

We therefore define primary and secondary jobs on the basis of job duration, distinguishing "stable" jobs with a duration of three months or longer and "unstable" jobs that last less than three months. This means the type of job is defined ex post. ${ }^{1}$ When an individual accepts a job, the characteristics of that job determine the likelihood that it ends within three months. Ideally, the distinction between primary and secondary jobs would be based upon these characteristics, but many of these are not observed (perhaps not even to the worker). Still, we expect that operationalizing the concept of primary and secondary jobs through job duration is useful, since job quality and duration will be positively correlated. The threshold of three months gives approximately equal numbers of spells ending in stable and unstable jobs. We will also compare with results using definitions of stable and unstable jobs based upon different threshold durations (two months and six months) and with a definition based upon whether the contract is permanent or temporary, in order to investigate whether our definition gives insights that are in line with the concept of primary versus secondary jobs.

Our paper analyzes how the current economic crisis affects exits from unemployment to stable and unstable jobs. We compare unemployment duration patterns and their determinants in two time periods, a period of expansion (2005-2007) and the recent recession (2009-2011). We focus on exploring the factors that determine the likelihood of unemployment exits to any job and to stable and unstable jobs, where we consider personal characteristics, characteristics of the previous employment relation, and macroeconomic conditions.

\footnotetext{
${ }^{1}$ Another study that distinguishes between transitions to short and longer lasting jobs is Cockx and Picchio (2012). They consider the case of Belgium during a time period when jobs typically lasted much longer than in our sample, and used a duration cut-off of one year.
} 
The policy relevance seems obvious. Workers' Protection systems and labour market policies should account for relevant distinctions between work sectors and stages of the business cycle. If individual differences are the main component of variation in re-employment probabilities, it seems natural that policies should focus on those who have low re-employment probabilities.

The data we used come from the Longitudinal Working Lives Sample, based upon administrative records from the Spanish Social Security Administration. It contains detailed information on employment and unemployment transitions, individual and job characteristics. We construct two separate samples that include all the unemployment benefit spells (including multiple spells of the same individuals) that started in 2005 and in 2009, and we observe the individuals who enter unemployment in these years until the exit of their unemployment benefit spell or the end of the observation period - 30 September 2011 for the 2009 data and, to increase comparability, 30 September 2007 for the 2005 data. Thus, our data are not left-censored, but are right-censored for a limited number of long unemployment spells.

We first estimate a Multivariate Mixed Proportional Hazard (MMPH) Model with shared frailty for the single risk (exit to any job) for the two samples under study. The explanatory variables include individual characteristics, variables that relate to the individual's labour market history, and a business cycle indicator. We then estimate MMPH Models with two destination states. In order to allow for dependence among the two hazards, unobserved heterogeneity in the two hazards is modelled jointly, using a discrete distribution with three points of support.

The remainder of the paper is organized as follows. Section 2 explains the main characteristics of the unemployment benefit system in Spain. Section 3 describes the data. In section 4 we present the econometric framework of unemployment durations. Section 5 provides the main results. Conclusions are drawn in section 6.

\section{The Unemployment Benefit System in Spain}

We summarize the main aspects of the unemployment benefits in Spain (not considering agricultural workers who have a different arrangement) for the period under study, 2005-2011. ${ }^{2}$ The Unemployment Benefit System (UBS) mainly provides coverage to wage workers (excluding public servants and domestic employees) who lost their job and are willing to work. In addition, to be entitled to unemployment benefits a minimum period of contributions to the Social Security System is required. There are two levels of protection: contributory (Unemployment Insurance Benefit, UIB) and assistance (Unemployment Assistance Benefit, UAB). UIB, based on the actuarial and financial principles, covers unemployed workers who have contributed to the contingency of unemployment at least for 12 months in the period of reference (the last six years preceding the status of unemployment). On the other hand, $U A B$ is a means-tested benefit available to unemployed workers who are not entitled to a contributory

\footnotetext{
${ }^{2}$ The main legislation reference for the period under study is the Royal Legislative Decree No 1/1994 of 20 June, approving Codified Text of the General Law on Social Security.
} 
benefit, because they do not satisfy the requirements or because the UIB has expired. The minimum period of contribution required in this case is three months in the period of reference.

The UIB duration increases with the contribution record, presenting a ratio of approximately one month of benefit to three months of contributions, with a minimum benefit duration of four months and a maximum of 24 months. The UIB includes the benefit amount and the payment of contributions to the retirement contingency (largely paid by the Public Employment Service, SPEE). The benefit amount is equal to $70 \%$ (during the first 180 days) and $60 \%$ (from the $181^{\text {st }}$ day) of the average daily contributory base. This average is calculated on contributions made during the 180 days prior to unemployment. The amount of benefits is related to the wage level prior to unemployment, with maximum and minimum amounts that depend on the number of dependants below age 26. Table 1 presents these limits as a percentage of IPREM (a public index that is the basis for many benefit amounts, $€ 469.80$ per month in 2005) as well as the amounts in 2005. For instance, the monthly UIB amount in 2005 was between $€ 438.48$ (no dependent children) and €1,233.23 (two or more dependent children).

Table 1: Limits of UIB (monthly amount and percentage of IPREM) by number of dependants, 2005

\begin{tabular}{ccccc}
\hline $\begin{array}{c}\text { Number of dependants } \\
\text { younger than age 26 }\end{array}$ & $\begin{array}{c}\text { Minimum } \\
\text { Percentage of } \\
\text { IPREM }\end{array}$ & Euros of 2005 & $\begin{array}{c}\text { Mercentage of } \\
\text { IPREM }\end{array}$ & Euros of 2005 \\
\hline 2 or more & $107 \%$ & 586.47 & $225 \%$ & $1,233.23$ \\
$\mathbf{1}$ & $107 \%$ & 586.47 & $200 \%$ & $1,096.20$ \\
Any & $80 \%$ & 438.48 & $175 \%$ & 959.18 \\
\hline
\end{tabular}

Source: Own elaboration

Table 2: Duration of unemployment benefits (UIB and UAB)

\begin{tabular}{|c|c|c|c|c|c|}
\hline \multirow{3}{*}{$\begin{array}{l}\text { N. of months } \\
\text { contributed in the } \\
\text { last six years } \\
\text { (tenure) }\end{array}$} & \multirow{3}{*}{$\begin{array}{l}\text { Contributory } \\
\text { Unemployment Benefits } \\
\text { (months) }\end{array}$} & \multicolumn{4}{|c|}{ Assistance Benefits } \\
\hline & & \multicolumn{2}{|c|}{ With family responsibilities } & \multicolumn{2}{|c|}{ Without family responsibilities } \\
\hline & & $\begin{array}{c}\text { Younger than } 45 \\
\text { years old }\end{array}$ & $\begin{array}{l}\text { Older than } 44 \\
\text { years old }\end{array}$ & $\begin{array}{c}\text { Younger than } 45 \\
\text { years old }\end{array}$ & $\begin{array}{c}\text { Older than } 44 \\
\text { years old }\end{array}$ \\
\hline 3 & - & 3 & 3 & - & - \\
\hline 4 & - & 4 & 4 & - & - \\
\hline 5 & - & 5 & 5 & - & - \\
\hline $6-11$ & - & 21 & 21 & 6 & 6 \\
\hline $12-17$ & 4 & 18 & 24 & - & 6 \\
\hline $18-71$ & $\begin{array}{c}2 \mathrm{x} \text { integer(tenure } / 6)= \\
6,8,10 \ldots 22\end{array}$ & 24 & 30 & 6 & 6 \\
\hline 72 & 24 & 24 & 36 & - & 6 \\
\hline Older 52 years & - & \multicolumn{4}{|c|}{ Until the age of retirement } \\
\hline Others $\left({ }^{*}\right)$ & - & \multicolumn{4}{|c|}{6,12 or 18} \\
\hline
\end{tabular}

Source: Own elaboration from Toharia et al. (2010)

$(*)$ returning emigrants, released from prison, disabled but able to work.

The amount of the UAB benefit is not related to the previous wage, it is $80 \%$ of the IPREM. The benefit duration depends on the family responsibilities, the age of the recipient, and the length of the contributory period in the last six years. In Table 2 the unemployment benefit duration is summarized for both contributory (UIB) and non-contributory (UAB) benefits. For instance, the unemployment benefit 
duration is between 3 and 60 months for an unemployed worker older than 44 years with family responsibilities. If the unemployed worker is older than 52 years old and entitled to the retirement pension, the unemployment benefit may last until the age of retirement. ${ }^{3}$

\section{Data and descriptive statistics}

The data we use come from the Longitudinal Working Lives Sample ${ }^{4}$ (LWLS) based upon administrative records from the Spanish Social Security Administration (SSA). The LWLS is collected annually since 2004 and contains information of a four percent random sample of the population who ever had any relationship with the SSA in the sample period, as contributors or as benefit recipients. It has approximately one million people. It contains information on the labour market histories of the part of the adult population who have ever worked. This database is useful for our study because of its longitudinal design and the rich information on employment and unemployment transitions, individual characteristics, and job characteristics that it contains. Due to its longitudinal design, individuals in the 2004 LWLS remain in the sample as long as they have a relationship with SSA. This makes it possible to observe the labour market status of the individuals over time.

LWLS provides information on individual characteristics such as gender, age, and nationality, firm and job attributes such as firm size, sector of activity, and type of contract, as well as information related to contributory and non-contributory benefits. It therefore allows us to analyse how the probabilities that jobseekers find work correlate with individual characteristics, benefit receipt, and characteristics of the job that preceded the unemployment spell.

To compare the durations of unemployment spells in an expansion and a recession period, we construct two samples that include all the unemployment spells with any kind of benefits (including multiple spells of the same individuals) that started in 2005 and in 2009, observing them until either benefits or the observation period end. The latter is 30 September 2011 for the 2009 data and, to increase comparability, set to 30 September 2007 for the 2005 data. This is achieved by merging the data sets LWLS 2005-2006-2007 and LWLS 2009-2010-2011.

We apply several filters to our samples, described in detail in Table 5 (Appendix A). For instance, we remove individuals with incomplete information and drop overlapping spells. In addition, we do not consider workers from the agricultural sector, because of specific benefit arrangements in this sector (the "Agrarian Special Regime").

As explained in Section 1, we distinguish between exits from unemployment to stable and unstable jobs, where we define a stable job as a job that lasts for at least three months with the same company, including self-employment. In LWLS, about $40 \%$ of all new contracts starting in 2005 or 2009 have a

\footnotetext{
${ }^{3}$ Several changes were made in the reform of July 2012 (after our observation window). The main changes are: the entitlement age limit for unemployment benefits until retirement changed from 52 to 55 years; the unemployment benefit amount from the 180 st day changed from $60 \%$ to $50 \%$; 36 months of assistance benefit for those older than 44 years old with at least 72 months of contributions become 30 months.

${ }^{4}$ For a detailed description of this data set, see Duran (2007), García-Perez (2008) and Lapuerta (2010).
} 
duration shorter than three months, suggesting that there is a significant flow of workers with high job turnover and unstable careers.

Our definition of unemployment spell is restricted to spells with receipt of benefits. Given that LWLS does not include information on spells of individuals without relationship with SSA, we cannot identify activity or inactivity when benefits are exhausted and the individual has not found a job. Accordingly, the length of the unemployment benefit spell is measured as the difference (in days) between the date of entry into unemployment and the transition from unemployment to employment. If at the end of the observation period the worker is still receiving unemployment benefits, data are considered rightcensored. Any exit other than finding a job is also treated as right-censoring.

\section{Descriptive analysis}

Our samples consist of 75,817 individuals with 91,787 unemployment spells in 2005, and 124,486 individuals with 158,363 unemployment spells in 2009. The difference between the two years reflects the large increase of the number of transitions into unemployment between 2005 and 2009. Of the spells starting in $2005,38 \%$ ended with an exit to a stable job and $26 \%$ with an exit to an unstable job. In 2009 , only $33 \%$ exited to a stable job, while the fraction of exits to an unstable job remained $26 \%$. The Kaplan Meier survival functions in Figure 1 show the probability of not having found a job as a function of spell duration $t$ for men and women. During the crisis the median unemployment duration has increased, from 110 days in 2005 to 240 days in 2009 for males, and from 150 to 240 days for females.

Figure 1: Kaplan Meier Survival estimates; exits from unemployment to any job. 2005 and 2009 samples. Durations in days.

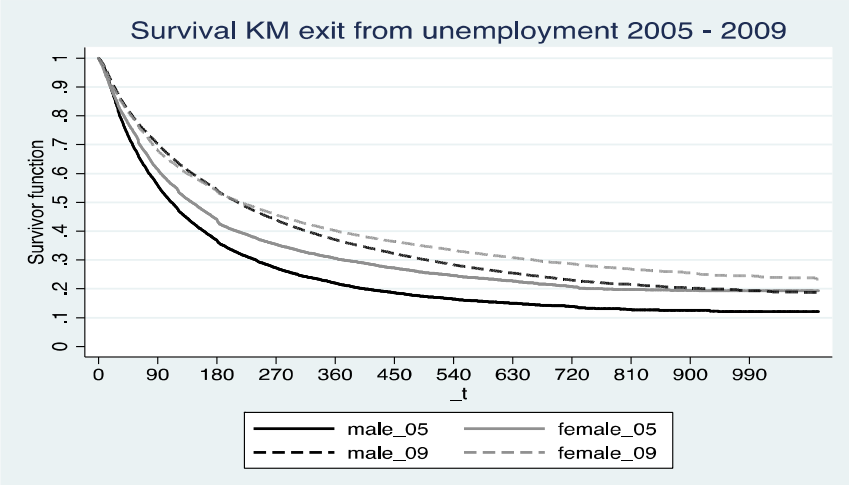

Source: Own elaboration from LWLS.

Figure 2 shows Kaplan Meier survival functions for exits to stable and unstable jobs by gender (treating transitions to the other type of job as right-censored observations). Exits to stable as well as unstable jobs are much less likely in 2009 than in 2005 for both men and women. The largest difference is found for stable jobs of men. For example, the probability that an unemployed man found a stable job within a year fell from $61 \%$ in 2005 to $45 \%$ in 2009 . For women, the same probability fell from about $52 \%$ to about $45 \%$. Thus women had lower chances than men to find a stable job before the crisis but similar 
chances during the crisis. The probability to find an unstable job within a year fell from $45 \%$ to $39 \%$ for men and from $37 \%$ to $31 \%$ for women - substantial reductions but not as dramatic as the men's drop for stable jobs. As a result, the survival functions for stable jobs tend to converge during the recession.

Another way to show the same differences is to consider median durations. Specifically, in the 2005 sample, 50\% of unemployed men had found a stable job after 200 days of unemployment, but in 2009 this had changed to after 470 days. On the other hand, the median durations for women's stable job durations changed much less - from 315 days in 2005 to 470 days in 2009. For unstable jobs, the medians also increase from 2005 to 2009 and they are always larger than the medians for stable jobs.

Figure 2: Kaplan Meier Survival estimates; exits from unemployment to stable and unstable jobs by gender. 2005 and 2009 samples. Durations in days.
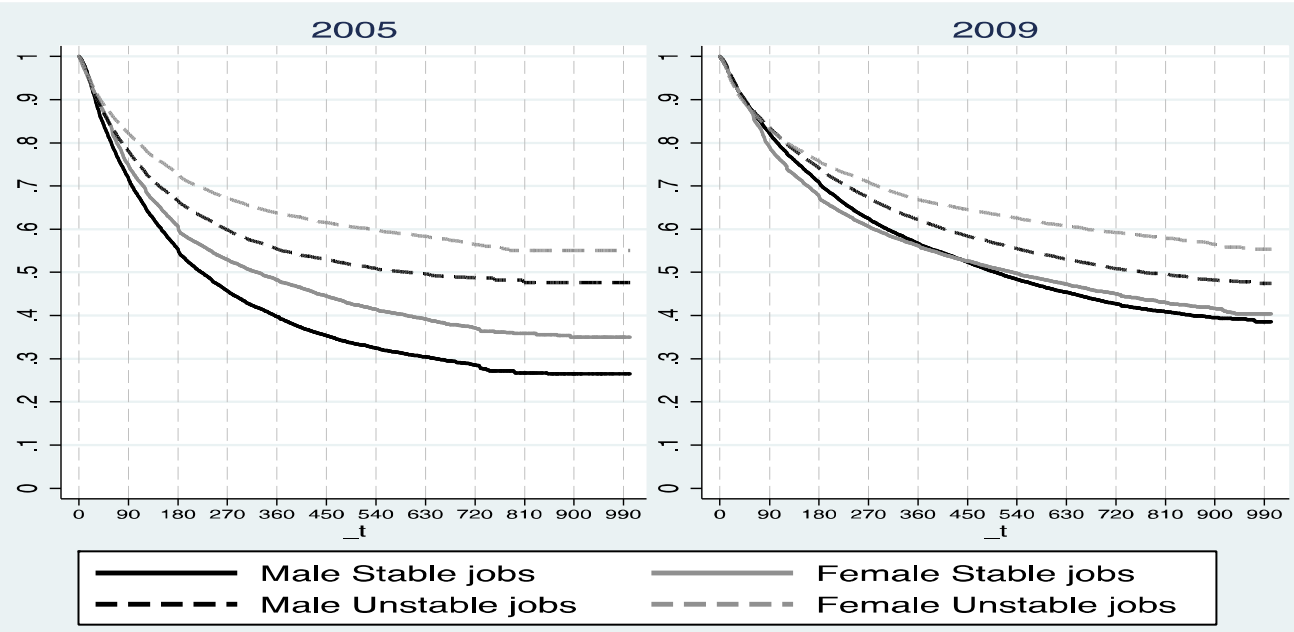

Source: Own elaboration from $L W L S$.

The estimated hazard rates corresponding to these survival functions are sketched in Figures 3 and 4. The estimates use the Kernel smoothing method; the empirical hazard rate at time $t$ is the proportion of individuals unemployed for at least $\mathrm{t}$ days that find a job between $\mathrm{t}$ and $\mathrm{t}+\Delta$, where $\Delta$ is one day. Figure 3 shows that the highest impact of the crisis on unemployment exits is found for males, particularly in the first year of the spell. The hazard in Figure 3 is the sum of the hazards to stable and unstable jobs in Figure 4. The latter confirms that the largest effect of the crisis is for males' transitions to stable jobs. The drop is less important for transitions to unstable jobs, since this hazard was already low in 2005. There is a negative association between each hazard rate and the duration of the spell in all cases, and it is stronger for transitions to stable jobs in 2005 (particularly for men but also for women). An exception is the peak in the hazard after two years of unemployment, which corresponds to the maximum duration of contributory unemployment benefits. The negative associations generally may reflect both genuine negative state dependence and spurious negative state dependence due to heterogeneity and the changing nature of the pool of unemployed over time. These explanations will be disentangled in the econometric model. 
Figure 3: Kaplan-Meier kernel smoothed hazard functions by gender; exits from unemployment to any job; 2005 and 2009 samples.

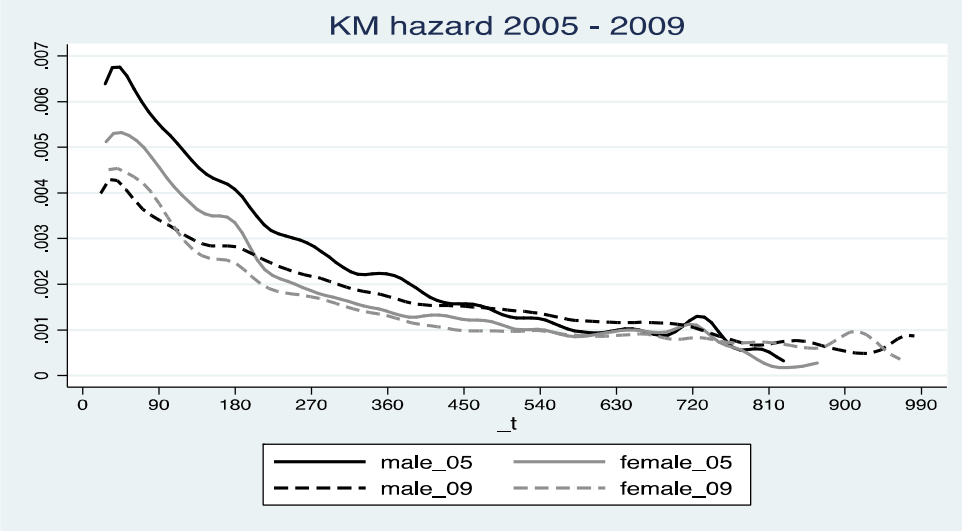

Source: Own elaboration from LWLS.

Figure 4: Kaplan-Meier kernel smoothed hazard functions by gender; exits from unemployment to stable and unstable jobs, 2005 and 2009 samples.

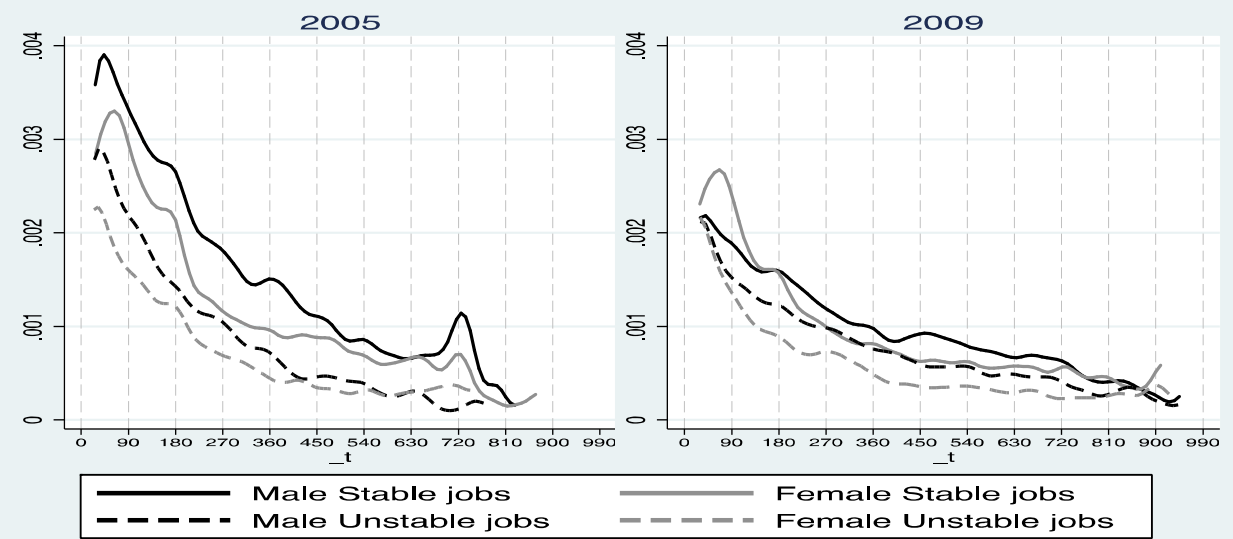

Source: Own elaboration from LWLS.

Note: Durations in days.

The Kaplan-Meier Survival estimates distinguishing unemployment exits by type of contract in Table 5 (Appendix A) show that exits to fixed-term contracts are much more likely than exits to jobs with permanent contracts, both in the expansion and recession periods. This makes the distinction by type of contract less informative - the shape of the overall survival function is largely determined by that for exits to fixed-term contracts. Females are more prone to find permanent jobs than males, but males have more chances to exit to fixed-term contracts in both samples.

According to job search theory, the probability to exit from unemployment into employment depends, on the one hand, on variables that affect the probability of receiving a job offer, such as the unemployment rate and the level of education, and on the other hand, on variables that affect the probability to accept an offer, such as having family responsibilities. For this reason, we consider as explanatory variables in our duration model personal characteristics, macroeconomic variables, and previous job and labour market history variables. All of these variables, except unemployment rates, 
come from LWLS. The (quarterly) regional unemployment rate comes from the Spanish Labour Force Survey. Table 3 provides some descriptive statistics of the explanatory variables in both samples.

Table 3: Descriptive statistics for the 2005 and 2009 samples.

\begin{tabular}{|c|c|c|c|c|}
\hline \multirow[b]{2}{*}{ Variable } & \multicolumn{2}{|c|}{2005} & \multicolumn{2}{|c|}{2009} \\
\hline & Mean & Std. Dev & Mean & Std. Dev \\
\hline \multicolumn{5}{|c|}{ MACROECONOMIC VARIABLES } \\
\hline Unemployment rate (quarterly) & 0.096 & 0.043 & 0.20 & 0.054 \\
\hline Male unemployment rate (quarterly) & 0.072 & 0.023 & 0.194 & 0.052 \\
\hline Female unemployment rate of (quarterly) & 0.118 & 0.046 & 0.199 & 0.057 \\
\hline Inhabitants $>40,000$ & 0.48 & 0.499 & 0.516 & 0.50 \\
\hline \multicolumn{5}{|c|}{ INDIVIDUAL CHARACTERISTICS } \\
\hline Male & 0.51 & 0.50 & 0.57 & 0.50 \\
\hline Age at the year of starting the unemployment spell & 36.81 & 10.87 & 37.07 & 10.67 \\
\hline Spanish native & 0.92 & 0.27 & 0.83 & 0.38 \\
\hline Spanish speaking immigrants & 0.03 & 0.17 & 0.06 & 0.24 \\
\hline Non-Spanish speaking immigrants & 0.05 & 0.22 & 0.11 & 0.32 \\
\hline Dummy dependent children & 0.26 & 0.44 & 0.25 & 0.44 \\
\hline High skilled & 0.34 & 0.47 & 0.36 & 0.48 \\
\hline Medium skilled & 0.36 & 0.48 & 0.36 & 0.48 \\
\hline Low skilled & 0.30 & 0.46 & 0.27 & 0.45 \\
\hline Non-manual occupation & 0.55 & 0.50 & 0.58 & 0.49 \\
\hline \multicolumn{5}{|c|}{ PREVIOUS JOB AND LABOUR MARKET HISTORY } \\
\hline Construction & 0.17 & 0.37 & 0.23 & 0.42 \\
\hline Manufacturing & 0.18 & 0.39 & 0.14 & 0.35 \\
\hline Services & 0.65 & 0.48 & 0.62 & 0.48 \\
\hline Dummy previous contract was temporary & 0.68 & 0.47 & 0.65 & 0.48 \\
\hline Dummy previous contract was on-call temporary & 0.07 & 0.26 & 0.08 & 0.27 \\
\hline Dummy previous contract was open-ended & 0.08 & 0.28 & 0.07 & 0.25 \\
\hline Dummy previous contract was permanent & 0.16 & 0.36 & 0.21 & 0.41 \\
\hline Dummy previous contract was part-time & 0.14 & 0.34 & 0.17 & 0.38 \\
\hline Duration of previous contract (days) & 374.81 & 820.19 & 403.26 & 866.99 \\
\hline Dummy firm size missing & 0.24 & 0.43 & 0.36 & 0.48 \\
\hline Size_1_9 in previous firm & 0.21 & 0.41 & 0.19 & 0.40 \\
\hline Size_10_19 in previous firm & 0.09 & 0.29 & 0.07 & 0.26 \\
\hline Size_20_49 in previous firm & 0.12 & 0.33 & 0.09 & 0.29 \\
\hline Size_50-249 in previous firm & 0.17 & 0.38 & 0.14 & 0.35 \\
\hline Size_250 in previous firm & 0.16 & 0.37 & 0.14 & 0.35 \\
\hline Historical use of Unemployment Benefits & 0.14 & 0.14 & 0.12 & 0.13 \\
\hline
\end{tabular}

Source: Own calculations using LWLS and the Economically Active Population Survey.

Note: Variable definitions are given in Table 6 (Appendix A).

The average age at the time of becoming unemployed is about 37 years in both samples. It is important to note that during our observation window unemployed workers older than 51 years who satisfy all the requirements for a retirement pension, were elegible to receive UAB until rement age. We therefore expect a lower probability to find a job for this group.

Only $26 \%$ of the samples have dependent children. Most unemployed workers have Spanish nationality - 92\% in the 2005 sample and 83\% in the 2009 sample. The proportion of non-Spanishspeaking unemployed immigrants increased from 5\% in 2005 to $11 \%$ in 2009, while the fraction of Spanish-speaking immigrants increased from 3\% to $6 \%$.

The personal characteristics we consider are gender, age, education level, nationality, and dependent children. Unlike studies that analyze men only (for example Arulampalam and Stewart, 1995, and Jenkins and Garcia-Serrano, 2004), we can analyze how the probability of finding a job differs by 
gender. In 2005, about 51\% of the sample were males, but in 2009 this proportion had risen to $57 \%$, reflecting the larger growth in unemployment of males compared to females due to the crisis.

We do not have information on formal education but use job category based upon the required level of skills for the job, registered for each worker, corresponding to the highest level of qualification required along their careers. Following Arranz and García-Serrano (2011), we create three categories (High-Medium-Low), defined separately for manual and non-manual occupations. The distribution of the workers by job category is similar in both samples. The largest group is medium-skilled (36\%). About 55\% (58\%) of the sample belongs to non-manual occupations in the 2005 (2009) sample.

To account for the business cycle we use the quarterly unemployment rate by region and gender. The average unemployment rate in the crisis period $(20 \%)$ is on average twice that during the expansion (10\%). Moreover, unemployment rates show important differences by region. Degree of urbanization is captured by a dummy for living in a larger municipality. Around $50 \%$ of workers live in a municipality with more than 40,000 inhabitants.

The sector of activity assigned is based on the sector in which the individual has been working longest. Sectors are grouped into construction, services and manufacturing industry. Varying unemployment rates across sectors might affect the probability to find a job. Most of the workers who became unemployed in 2005 are from the services sector (65\%). The proportion of individuals from the manufacturing industry and construction sector are $18 \%$ and $17 \%$, respectively. With the burst of the property bubble, these proportions changed in 2009 , with an increase to $23 \%$ in construction and decreases in manufacturing and services.

Information on the size of the firm (number of employees) is not always available, and we include a dummy for these missing values. ${ }^{5}$ Duration and type of previous contract might provide information on worker productivity - workers with fixed-term and shorter contracts are more likely to be less productive and to have less stable careers than those with permanent and longer contracts. The average duration of the former contract has increased from 374.8 in 2005 to 403.3 days in 2009, implying that more experienced workers have become unemployed during the downturn. The previous contract duration is also a proxy of the period a worker is entitled to an unemployment benefit.

Since their introduction in 1984, fixed-term contracts are used extensively, representing over $25 \%$ of all employment contracts in recent years. Firing costs are lower for workers on fixed-term contracts than for permanent hires. The majority of the workers in our samples had a temporary contract before becoming unemployed - around $84 \%$ in 2005 , falling to $79 \%$ in 2009 . Open-ended contracts are especially set up for adjusting the seasonality of the activities, as they allow for interruptions of labour relation due to seasonality. This type of contract is found in about $8 \%$ of the former jobs. Unlike the extensive use of fix-term contracts in Spain, the proportion of part time jobs is

\footnotetext{
${ }^{5}$ The main reason is that the information on firm size in the LWLS of a given year is based upon administrative records collected in March of the next year. For many workers, the firm at which they had their last job no longer exists at that time, particularly during the crisis.
} 
lower than the European average. The average number of former part time contracts is $14 \%$ in 2005 , increasing to $17 \%$ in 2009.

The final variable in Table 3, the historical use of Unemployment Benefits, is the ratio of the number of days on unemployment benefits and the number of days the individual contributed to unemployment benefits. It fell from 14\% in 2005 to 12\% in 2009, implying that the unemployed in the 2009 sample had more stable working careers.

\section{Econometric framework}

To analyse the determinants of unemployment durations, we use both a single risk model (exits from an unemployment benefit spell to any job) and a competing risk model (distinguishing between exits to stable and unstable jobs).

\section{Single risk model}

Since unemployment durations are measured in days, we consider the duration of each unemployment spell as a continuous random variable. The unemployment hazard rate at duration $t$ is the probability of leaving unemployment at spell length $t$ conditional on not leaving unemployment earlier. Formally the hazard rate is defined as:

$$
h(t)=f(t) / S(t)
$$

Here $f(t)$ represents the density function of the unemployment durations and $S(t)$ is the survival function given by $S(t)=1-F(t)$, where $F(t)$ is the cumulative density function of the durations. The interpretation of this continuous time hazard rate is that the conditional probability of leaving unemployment in the short time interval $(t, t+\Delta)$ is approximately $h(t) \Delta$.

We specify the hazard using the multiple-spell data extension of the Mixed Proportional Hazard (MPH) model, using gap time representation: time is reset to zero after each event (see, e.g., van den Berg, 2001). The conditional hazard function evaluated at spell duration $t$ for the $s$-th spell of individual $i$ is given by the product of the baseline hazard, $h_{0}(t)$, an observed heterogeneity factor, $X_{i s}(t)^{\prime} \beta$, including time-varying covariates (and excluding the intercept, by means of normalization needed to identify the model) and an unobserved heterogeneity ("frailty") component $u_{i s}$ :

$$
h\left(t_{i s} \mid X_{i s}(t), u_{i s}\right)=u_{i s} \cdot h_{0}(t) \cdot \exp \left(X_{i s}(t)^{\prime} \beta\right)
$$

We assume that the baseline hazard $\left(h_{0}(t)\right)$ follows an exponential distribution with piecewise constant duration dependence (using mainly quarterly cut-points). This implies that the baseline hazard rate is constant within each interval but may change between intervals $(k)$ as follows:

$$
h_{0}(t)=\bar{h}_{k} t \in\left(\tau_{k-1}, \tau_{k}\right), k=1, \ldots, K
$$

This baseline hazard specification has the advantage of not imposing a particular functional form, thus allowing for a flexible shape of duration dependence. 
The main parameters of interest are in the vector $\beta$ indicating how the hazard varies with observed individual characteristics and labour market history variables. A positive coefficient of a covariate implies that, other things being equal (other covariates and unobserved heterogeneity), an increase in the covariate increases the probability to find a job. A way to interpret the size of the coefficients is through the percentage change in the hazard produced by a one unit change in the covariate, obtained as $\left(e^{\beta}-1\right) \cdot 100$.

The proportional hazard assumption implies that the shape of the duration dependence ("baseline hazard") is the same for all individuals; the covariates change the hazard rates with the same proportion at each $t$, so the level of the hazard may change across individuals.

We assume that all the spells of the same individual share the same frailty. In other words, unobserved heterogeneity is at the level of person $i: u_{i s}=u_{i}$. Conditional on observed heterogeneity $X_{i s}(t)$ and unobserved heterogeneity $u_{i}$ different durations of the same individual are independent.

We assume that the distribution of the frailty term $u_{i}$ is Inverse-Gaussian ${ }^{6}$ with mean normalized to 1 and with finite variance $\vartheta$. The parameter $\vartheta$ indicates the amount of unobserved heterogeneity and (since frailty is constant across spells of the same individual) may also be interpreted as a measure of correlation between recurrent events of the same individuals. The choice of this frailty distribution is justified by the fact that it gives a higher maximum likelihood than other common frailty distributions ${ }^{7}$. Ignoring unobserved heterogeneity may lead to biases in the coefficients on $X$ and would make the estimated duration dependence more negative (Nickell, 1979). The flexible baseline hazard and the inclusion of frailty in the model make it possible to analyse genuine duration dependence before and during the crisis. The model can be estimated by maximum likelihood, using standard Stata commands.

\section{Multi-state (exit to stable or unstable job): Competing risks model}

To analyse the unemployment duration pattern and the determinants of transitions out of unemployment into stable and unstable jobs (as well as into temporary and permanent contracts), we extend the single risk model using a competing risks framework (see, e.g., Kalbfleisch and Prentice, 2002, Chapter 8). An unemployment spell can end with a transition to a stable job ( $j=1$ ) or an unstable job ( $j=2)$. This gives a total hazard

$$
h(t)=h_{1}(t)+h_{2}(t)
$$

Here $h(t)$ is the hazard to exit to any job at unemployment duration $t$, and $h_{1}(t)$ and $h_{2}(t)$ are the hazards for exits to the two competing types of jobs, stable and unstable, respectively. Conditional on observed and unobserved heterogeneity, the competing risks are assumed to be independent. We specify the following Multivariate Mixed Proportional Hazard (MMPH) model with gap-time

\footnotetext{
${ }^{6}$ The density is: $f(x ; \vartheta)=(2 \pi \vartheta)^{-0.5} x^{-1.5} e^{-(x-1)^{2} /(2 \vartheta x)}$

${ }^{7}$ Estimations assuming shared frailty heterogeneity fit better than estimations under unshared frailty for different distributions of the unobserved heterogeneity.
} 
representation with hazards $h_{j}\left(t \mid X_{i}(t), V_{i}^{j}\right)$ for the two types of transitions $j=1,2$, of individual $i$ conditional on observed and unobserved characteristics:

$$
h_{j}\left(t \mid X_{i}(t), V_{i}^{j}\right)=h_{0}^{j}(t) \cdot \exp \left(X_{i}(t)^{\prime} \beta^{j}\right) \cdot \exp \left(V_{i}^{j}\right)
$$

The baseline hazard for the transitions $j=1,2, h_{0}^{j}(t)$, is specified as piecewise constant with mainly quarterly cut points (as for the single risk model). Analogous to the single risk model, the parameters of main interest are the vectors $\beta^{j}, j=1,2$, which determine how the two hazards vary with the individual characteristics. A positive coefficient of a covariate implies that, conditional to the unobserved heterogeneity, this covariate, other things being equal, increases the probability to find a stable $(j=1)$ or unstable $(j=2)$ job.

The unobserved heterogeneity terms are $V_{i}^{j}$. Following Heckman and Singer (1984), we use discrete frailty, and we allow $V_{i}^{1}$ and $V_{i}^{2}$ to be correlated. This discrete distribution is computationally easier than continuous distributions. Moreover, it is very common in the literature on labour market transitions; see, for instance, Bover, Arellano and Bentolila (2002), Rebollo-Sanz (2012), Arranz et al. (2010), or Bijwaard and Wahba (2014).

Under a discrete frailty distribution, the population consists of two (or more) homogeneous subpopulations with different risks. For instance, one group of motivated individuals could have higher exit probabilities for all types of jobs, another group might have very low chances of finding a stable job but good prospects for an unstable job, etc. The group to which an individual belongs, however, is never observed. The population fractions of the groups are unknown parameters $p_{k}{ }^{8}$ The number of groups is denoted by $K$, with $\sum_{k=1}^{K} p_{k}=1 ; K$ is also the number of mass points of the distribution of $\left(V_{i}^{1}, V_{i}^{2}\right)$.

We assume that unobserved heterogeneity is constant over time (within and across spells of the same individual). For identification, we also assume it is independent of observed characteristics, the standard assumption in this kind of duration models (van den Berg, 2001). Moreover, since we do not impose a normalization on the baseline hazard or on $X_{i}(t)^{\prime} \beta^{j}$, we need to impose $E\left(V^{j}\right)=0: \sum_{k=1}^{K} p_{k} V^{j}=0$ for $j=1,2$ as a normalization.

All parameters are estimated jointly by Maximum Likelihood. The likelihood function is, under the independence assumption, the product of the Likelihood function of all the individuals (i), $L=\prod_{i} L_{i}$. The likelihood contribution $L_{i}$ of individual $i$ for two competing risks $(j=1,2)$ can be written as the expected value of the conditional likelihood given $\left(V_{i}^{1}, V_{i}^{2}\right): \quad L_{i}=\sum_{k=1}^{K} P_{k} \cdot L_{i}\left(V^{k}\right)$, where $L_{i}\left(V^{k}\right)$ is the conditional likelihood contribution given $\left(V_{i}^{1}, V_{i}^{2}\right)$ is equal to the $k^{\text {th }}$ mass point $V^{k}=\left(V_{k}^{1}, V_{k}^{2}\right)$. This conditional likelihood contribution is a standard likelihood contribution in a model without unobserved

\footnotetext{
${ }^{8}$ To ensure the probability is between zero and one we assume $p_{k}=\frac{\exp \left(a_{k}\right)}{\left(1+\sum_{l=1}^{K-1} \exp \left(a_{l}\right)\right)}$
} 
heterogeneity; it includes the conditional density function for the observed exits of the completed spells and the conditional survival function for right-censored spells at each competing risks (j):

$$
L_{i}\left(V^{k}\right)=\prod_{j=1}^{2} \prod_{s=1}^{S} h_{s}^{j}\left(t_{i} \mid X_{i}(s), V_{j}^{k}\right)^{d_{i, j, s}} \cdot S_{s}^{j}\left(t_{i} \mid X_{i}(s), V_{j}^{k}\right)
$$

Here $s=1, \ldots, S$ are the spells of individual $i$, and $d_{i, j, s}$ is a dummy that is 1 if spell $s$ ends in a transition of type $j$ and 0 otherwise. Our estimates are obtained using the Stata code of Bijwaard (2014).

\section{Estimation results}

We estimated several specifications of the single and competing risk models. Table 4 presents the results for our benchmark models. Estimates for alternative specifications are presented in the appendix and briefly discussed below. The single risk benchmark model has a flexible piecewise constant baseline hazard and a shared inverse Gaussian distribution of unobserved heterogeneity, since this specification gave a better likelihood than several alternatives (such as unshared distributions or a shared gamma distribution). For the competing risks model, the best likelihood is obtained using a discrete unobserved heterogeneity distribution with three mass points. ${ }^{9}$ The benchmark model includes personal characteristics, a business cycle indicator, and previous job and labour market history variables.

\section{Local unemployment rate}

One of the main determinants of the unemployment durations is the (quarterly) local unemployment rate. As expected, an unemployed person in a region with a high unemployment rate has a smaller probability of receiving a job offer and therefore a longer unemployment spell than a similar person in a region with a low unemployment rate. This is consistent with other findings for Spain like Arranz and Muro (2004), Alba et al. (2012), Arranz et al. (2010) and Bover, Arellano and Bentolila (2002). Other than in the UK study of Arulampalam and Stewart (1995), the coefficient of the unemployment rate in the single risk model is lower in absolute value for the recession period than during the expansion. Still, since unemployment rates are much higher during the economic downturn (Table 3), the corresponding elasticity of the hazard for the local unemployment rate increases in absolute value, from -0.25 in the expansion period to -0.39 in the downturn.

For exits to stable (primary) jobs, the elasticity falls from -0.38 in the expansion period to -0.36 in the recession, perhaps since during the crisis the unemployed are more willing to look for a stable job outside their own region. The effect of the local unemployment rate is smaller for the hazard to unstable jobs, particularly in 2005 (where it is also insignificant). The higher effect of the unemployment rate in exits to stable jobs might be due to the fact that the lower (primary or secondary) job offer rates are partly compensated by a higher willingness to accept an unstable (secondary) job.

\footnotetext{
${ }^{9}$ The model with three mass points is significantly better than the model with two mass points. For the correlated competing risks model with four mass points we did not obtain convergence.
} 
Table 4: Estimation results of models with single risk (exit to any job) and correlated competing risks (exit to stable and unstable jobs); 2005 and 2009 samples.

\begin{tabular}{|c|c|c|c|c|c|c|}
\hline & \multicolumn{3}{|c|}{2005 sample } & \multicolumn{3}{|c|}{2009 sample } \\
\hline & Any job & Stable & Unstable & Any job & Stable & Unstable \\
\hline \multirow[t]{2}{*}{ Unemployment rate } & $-2.499 * * *$ & $-3.781 * * *$ & -0.238 & $-1.973^{* * *}$ & $-1.792^{* * *}$ & $-1.496 * * *$ \\
\hline & $(0.151)$ & $(0.174)$ & $(0.220)$ & (0.0879) & $(0.0922)$ & $(0.120)$ \\
\hline \multirow[t]{2}{*}{ Male } & $0.262 * * *$ & $0.176 * * *$ & $0.329 * * *$ & $0.159 * * *$ & $0.111^{* * *}$ & $0.123 * * *$ \\
\hline & $(0.0144)$ & $(0.0150)$ & $(0.0215)$ & $(0.0112)$ & $(0.0112)$ & $(0.0154)$ \\
\hline \multirow[t]{2}{*}{ Aged_16_19 } & 0.117 & 0.000839 & $0.295 * * *$ & -0.0159 & -0.103 & $0.159^{*}$ \\
\hline & $(0.0755)$ & $(0.0923)$ & $(0.106)$ & $(0.0695)$ & $(0.0870)$ & $(0.0934)$ \\
\hline \multirow[t]{2}{*}{ Aged_20_24 } & $0.295 * * *$ & $0.249 * * *$ & $0.340 * * *$ & $0.154 * * *$ & $0.0948 * * *$ & $0.275^{* * *}$ \\
\hline & $(0.0276)$ & $(0.0297)$ & $(0.0409)$ & $(0.0232)$ & $(0.0250)$ & $(0.0318)$ \\
\hline \multirow[t]{2}{*}{ Aged_25_29 } & $0.377 * * *$ & $0.359 * * *$ & $0.343 * * *$ & $0.326 * * *$ & $0.253 * * *$ & $0.398 * * *$ \\
\hline & $(0.0239)$ & $(0.0250)$ & $(0.0356)$ & $(0.0197)$ & $(0.0207)$ & $(0.0272)$ \\
\hline \multirow[t]{2}{*}{ Aged_30_34 } & $0.379 * * *$ & $0.358 * * *$ & $0.331 * * *$ & $0.333 * * *$ & $0.297 * * *$ & $0.366 * * *$ \\
\hline & $(0.0235)$ & $(0.0244)$ & $(0.0352)$ & $(0.0191)$ & $(0.0196)$ & $(0.0264)$ \\
\hline \multirow[t]{2}{*}{ Aged_35_39 } & $0.401 * * *$ & $0.372 * * *$ & $0.378 * * *$ & $0.315^{* * *}$ & $0.297 * * *$ & $0.329 * * *$ \\
\hline & $(0.0241)$ & $(0.0251)$ & $(0.0361)$ & $(0.0194)$ & (0.0199) & $(0.0270)$ \\
\hline \multirow[t]{2}{*}{ Aged_40_44 } & $0.442 * * *$ & $0.387^{* * *}$ & $0.436 * * *$ & $0.313^{* * *}$ & $0.299 * * *$ & $0.340 * * *$ \\
\hline & $(0.0248)$ & $(0.0257)$ & $(0.0371)$ & $(0.0201)$ & $(0.0205)$ & $(0.0279)$ \\
\hline \multirow[t]{2}{*}{ Aged_45_51 } & $0.410 * * *$ & $0.369 * * *$ & $0.372 * * *$ & $0.273 * * *$ & $0.281 * * *$ & $0.286 * * *$ \\
\hline & $(0.0245)$ & $(0.0254)$ & $(0.0370)$ & $(0.0195)$ & (0.0199) & $(0.0274)$ \\
\hline \multirow[t]{2}{*}{ Older61 } & $-0.699 * * *$ & $-0.605 * * *$ & $-0.667 * * *$ & $-0.546 * * *$ & $-0.496 * * *$ & $-0.586 * * *$ \\
\hline & $(0.0360)$ & $(0.0385)$ & $(0.0582)$ & $(0.0295)$ & $(0.0307)$ & $(0.0456)$ \\
\hline Spanish speaking & $-0.0664^{*}$ & $-0.105^{* * *}$ & 0.0593 & $-0.207 * * *$ & $-0.325 * * *$ & -0.0320 \\
\hline immigrants & $(0.0341)$ & $(0.0369)$ & $(0.0497)$ & $(0.0206)$ & $(0.0233)$ & $(0.0267)$ \\
\hline Non Spanish speaking & $-0.236 * * *$ & $-0.224 * * *$ & $-0.162 * * *$ & $-0.447^{* * *}$ & $-0.429 * * *$ & $-0.419 * * *$ \\
\hline immigrants & $(0.0271)$ & $(0.0290)$ & $(0.0405)$ & $(0.0162)$ & $(0.0174)$ & $(0.0219)$ \\
\hline \multirow[t]{2}{*}{ Dependent children } & $0.141^{* * *}$ & $0.138 * * *$ & $0.0941^{* * *}$ & $0.180 * * *$ & $0.163 * * *$ & $0.133^{* * *}$ \\
\hline & $(0.0129)$ & $(0.0131)$ & $(0.0191)$ & $(0.0107)$ & $(0.0107)$ & $(0.0145)$ \\
\hline \multirow[t]{2}{*}{ Inhabitants $>40,000$} & 0.00215 & -0.000919 & 0.00258 & $-0.129 * * *$ & $-0.117^{* * *}$ & $-0.110 * * *$ \\
\hline & $(0.0114)$ & $(0.0119)$ & $(0.0168)$ & $(0.00942)$ & $(0.00968)$ & $(0.0128)$ \\
\hline High skilled & $0.126 * * *$ & $0.180 * * *$ & $0.0427^{*}$ & $0.271 * * *$ & $0.273 * * *$ & $0.173 * * *$ \\
\hline & $(0.0153)$ & $(0.0160)$ & $(0.0224)$ & $(0.0134)$ & $(0.0140)$ & $(0.0182)$ \\
\hline Medium skilled & -0.0113 & $0.0259 *$ & $-0.0393 *$ & $0.0995 * * *$ & $0.0838 * * *$ & $0.0778 * * *$ \\
\hline & $(0.0138)$ & $(0.0146)$ & $(0.0203)$ & $(0.0120)$ & $(0.0126)$ & $(0.0162)$ \\
\hline Non manual & $0.0284^{* *}$ & $0.0693 * * *$ & -0.0134 & $0.0774 * * *$ & $0.0992 * * *$ & $0.0309^{*}$ \\
\hline & $(0.0135)$ & $(0.0140)$ & $(0.0201)$ & $(0.0120)$ & $(0.0122)$ & $(0.0165)$ \\
\hline Construction & $0.221 * * *$ & $0.184^{* * *}$ & $0.211 * * *$ & $0.0763 * * *$ & $-0.0437 * * *$ & $0.243^{* * *}$ \\
\hline & (0.0173) & $(0.0180)$ & $(0.0250)$ & $(0.0135)$ & $(0.0141)$ & $(0.0181)$ \\
\hline Manufacturing & $0.0806^{* * *}$ & $0.0273^{*}$ & $0.123 * * *$ & $0.113 * * *$ & -0.00922 & $0.217 * * *$ \\
\hline & $(0.0153)$ & (0.0159) & $(0.0227)$ & $(0.0141)$ & $(0.0143)$ & $(0.0193)$ \\
\hline Firm size missing & $0.0625^{* * *}$ & -0.0110 & $0.154 * * *$ & $0.0554 * * *$ & $-0.0400 * * *$ & $0.162 * * *$ \\
\hline & $(0.0163)$ & $(0.0173)$ & $(0.0244)$ & $(0.0128)$ & $(0.0135)$ & $(0.0178)$ \\
\hline Size_10_19 & $0.110 * * *$ & $0.0830 * * *$ & $0.117^{* * *}$ & $0.0867 * * *$ & $0.0590 * * *$ & $0.108 * * *$ \\
\hline & $(0.0215)$ & $(0.0226)$ & $(0.0323)$ & $(0.0195)$ & $(0.0205)$ & $(0.0276)$ \\
\hline Size_20_49 & $0.206 * * *$ & $0.164 * * *$ & $0.223 * * *$ & $0.170 * * *$ & $0.107^{* * *}$ & $0.210 * * *$ \\
\hline & $(0.0195)$ & $(0.0204)$ & $(0.0296)$ & $(0.0178)$ & $(0.0184)$ & $(0.0248)$ \\
\hline Size_50_249 & $0.251 * * *$ & $0.184 * * *$ & $0.297 * * *$ & $0.286 * * *$ & $0.205^{* * *}$ & $0.315^{* * *}$ \\
\hline & $(0.0177)$ & $(0.0186)$ & $(0.0268)$ & $(0.0158)$ & $(0.0162)$ & $(0.0220)$ \\
\hline Size_250 & $0.315 * * *$ & $0.198 * * *$ & $0.442 * * *$ & $0.462 * * *$ & $0.298 * * *$ & $0.510 * * *$ \\
\hline & $(0.0189)$ & (0.0199) & $(0.0279)$ & $(0.0167)$ & $(0.0171)$ & $(0.0229)$ \\
\hline Open-ended contract & $1.675^{* * *}$ & $1.775 * * *$ & $0.663 * * *$ & $1.894 * * *$ & $1.984 * * *$ & $1.039 * * *$ \\
\hline & $(0.0263)$ & $(0.0265)$ & $(0.0486)$ & $(0.0218)$ & $(0.0205)$ & $(0.0355)$ \\
\hline Temporary contract & $0.722 * * *$ & $0.523 * * *$ & $0.674 * * *$ & $0.748 * * *$ & $0.484^{* * *}$ & $0.742 * * *$ \\
\hline & $(0.0190)$ & $(0.0193)$ & $(0.0330)$ & $(0.0136)$ & $(0.0140)$ & $(0.0215)$ \\
\hline On-call contract & $1.346 * * *$ & $0.927 * * *$ & $1.386 * * *$ & $1.410^{* * *}$ & $0.870^{* * *}$ & $1.505^{* * *}$ \\
\hline & $(0.0273)$ & $(0.0292)$ & $(0.0422)$ & $(0.0209)$ & $(0.0224)$ & $(0.0291)$ \\
\hline Duration_1 & $-0.00017^{* * *}$ & $-0.000055^{* * *}$ & $-0.00076 * * *$ & $-0.000134 * * *$ & $-0.000047^{* * *}$ & $-0.00058 * * *$ \\
\hline & $(9.79 e-06)$ & $(8.42 \mathrm{e}-06)$ & $(2.79 \mathrm{e}-05)$ & $(7.02 \mathrm{e}-06)$ & $(6.28 \mathrm{e}-06)$ & $(1.74 \mathrm{e}-05)$ \\
\hline Part time coefficient_1 & $0.290 * * *$ & -0.0224 & $0.809 * * *$ & $0.0947^{* * *}$ & $-0.0443^{*}$ & $0.678^{* * *}$ \\
\hline & $(0.0350)$ & (0.0357) & $(0.0573)$ & $(0.0252)$ & $(0.0254)$ & (0.0389) \\
\hline Historical use of UB & $-0.499 * * *$ & $-0.638^{* * *}$ & $-0.106^{*}$ & $-0.977^{* * *}$ & $-1.186^{* * *}$ & $-0.382 * * *$ \\
\hline & $(0.0440)$ & $(0.0467)$ & $(0.0622)$ & $(0.0399)$ & $(0.0423)$ & $(0.0525)$ \\
\hline
\end{tabular}


Table 4, continued

\begin{tabular}{|c|c|c|c|c|c|c|}
\hline & \multicolumn{3}{|c|}{2005 sample } & \multicolumn{3}{|c|}{2009 sample } \\
\hline & Any job & Stable & Unstable & Any job & Stable & Unstable \\
\hline \multirow[t]{2}{*}{ In Theta } & -0.0343 & & & $0.297 * * *$ & & \\
\hline & $(0.0278)$ & & & $(0.0211)$ & & \\
\hline \multirow[t]{2}{*}{ V1 } & & $0.373 * * *$ & $1.637 * * *$ & & $0.545^{* * *}$ & $1.620 * * *$ \\
\hline & & $(0.0346)$ & $(0.0332)$ & & $(0.0217)$ & $(0.0214)$ \\
\hline \multirow[t]{2}{*}{ V2 } & & $2.180 * * *$ & $1.020 * * *$ & & $3.386 * * *$ & 0.344 \\
\hline & & $(0.0471)$ & $(0.141)$ & & $(0.0483)$ & $(0.232)$ \\
\hline \multirow[t]{2}{*}{ a1 } & & $-1.372 * * *$ & & & $-1.205^{* * *}$ & \\
\hline & & $(0.0753)$ & & & $(0.0431)$ & \\
\hline \multirow[t]{2}{*}{ a2 } & & $-3.424 * * *$ & & & $-4.496 * * *$ & \\
\hline & & $(0.106)$ & & & $(0.0722)$ & \\
\hline Number of individuals & 75,817 & 75,817 & & 124,486 & 124,486 & \\
\hline Number of exits & 58,435 & 34,918 & 23,517 & 93,808 & 52,111 & 41,697 \\
\hline Total number of spells & 91,787 & 91,787 & & 158,363 & 158,363 & \\
\hline Log Likelihood & $-124,903$ & $-398,732$ & & $-212,372$ & $-145,054$ & \\
\hline $\begin{array}{l}\text { Theta (parameter of } \\
\text { inverse Gaussian) }\end{array}$ & 0.97 & & & 1.35 & & \\
\hline \multicolumn{2}{|c|}{ Implied mass point distribution } & 1 & 2 & 3 & $E[V]$ & \\
\hline & Probability & $20 \%$ & $2 \%$ & $78 \%$ & & \\
\hline \multirow[t]{4}{*}{2005} & V stable & 0.37 & 2.18 & -0.17 & 0 & \\
\hline & V unstable & 1.64 & 1.02 & -0.45 & 0 & \\
\hline & Rho= & 0.68 & & & & \\
\hline & Probability & $23 \%$ & $1 \%$ & $76 \%$ & & \\
\hline \multirow[t]{3}{*}{2009} & V stable & 0.55 & 3.39 & -0.20 & 0 & \\
\hline & V unstable & 1.62 & 0.34 & -0.49 & 0 & \\
\hline & Rho= & 0.73 & & & & \\
\hline
\end{tabular}

Notes: Single risk estimation: piecewise baseline and shared frailty assuming inverse Gaussian distribution for unobserved heterogeneity. Both in 2005 and 2009 LR test show that frailty is significant ( $p$-value=0.000).

Correlated Competing risks estimation: piecewise baseline and discrete distribution of unobserved heterogeneity with three mass points.

References categories: female, low skilled level, manual occupation, Aged_52_61, services sector, size_1_9, permanent contract, Native Spanish. Age and quarterly unemployment rate are time-varying variables.

Significance levels: *** $\mathrm{p}<0.01, * * \mathrm{p}<0.05, * \mathrm{p}<0.1$

\section{Personal characteristics}

In line with Figure 2, men have larger hazard rates than women, particularly in the expansion period. An exit to any job is $30 \%$ more likely for a man than for an otherwise similar woman during the expansion period, and only $17 \%$ in the recession. Similar results are found by Arranz and Muro (2004), Arranz et al. (2010) and in Alba et al. (2012) for exits to new jobs (not recalls). The estimates distinguishing exits to stable and unstable jobs show that before the crisis, the gender difference was much larger for unstable than for stable jobs. The differences have fallen during the recession.

Age patterns are similar for both types of jobs except perhaps for the youngest age groups, who have a relatively higher probability of finding an unstable job. Compared to the reference group (ages 5260), workers of ages 20-51 have higher exit probabilities (that rise with age), while the unemployed older than 61 are much less likely to find a job of whatever type. The lower exit rates for the 52 and older group are in line with the literature (Bover and Gómez, 2004; Arranz et al. 2010; Bover et al., 2002). They may have higher reservation wages due to accumulated labour experience (Folmer and van Dijk, 1988) and more difficulties to adapt to a new job (Narendranathan and Nickell, 1985). In addition, there may 
be a disincentive effect of the special subsidy for older unemployed until retirement age. During the economic crisis, the age differences are smaller, so those with the highest exit rates - ages 16-24 and 4051 - suffer most from the crisis.

Unemployed immigrants suffer much more from the crisis than Spanish natives. In the expansion period mainly non-Spanish speaking immigrants already have lower exit probabilities than comparable native workers, but during the downturn, the difference increases. Accordingly, Arranz and MuñozBullón (2013) find that non-Spanish unemployed workers have a lower probability of being recalled. On the other hand, Rebollo-Sanz (2012, table A1) finds that the hazard of re-employment is higher for immigrants. Moreover, for unemployed Spanish speaking immigrants, the probability to find a stable job falls much more than for comparable natives, while they have the same unemployment duration patterns as Spanish workers in exits to unstable jobs in both periods.

The influence of the level of skills on the probability of finding a job is ambiguous from a theoretical and an empirical point of view. Search theory implies that a higher level of education is associated with more productivity (Toharia and Cebrián, 2007), implying on the one hand, higher arrival rates, and on the other hand, a higher reservation wage. Arranz and Muro (2004) find no significant effect of education, while according to Bover and Gómez (2004) having a university degree reduces the hazard rate to a temporary job but increases the hazard to a permanent job. In our estimations, a higher level of skills increases the probabilities of exits to any job for both periods under study. For stable jobs, the positive effects of higher skills are stronger in the crisis period than before the crisis, showing that employers exploit the larger supply to hire more skilled workers for stable jobs. For exits to unstable jobs, skill level is of minor importance during the expansion, perhaps since skilled workers were often not willing to accept unstable jobs. In contrast, during the downturn, higher skills also increase the chances to get an unstable job, suggesting that higher skilled workers substitute low skilled workers in unstable jobs. These results are therefore in line with the notion that during the recession, job seekers reduce their requirements of the type of job they are willing to accept, while employers are able to select more on skills. As a consequence, the low skilled unemployed suffer more from the crisis than those with higher skills. Similarly, unemployed workers from non-manual occupations experience higher exit rates than otherwise similar workers in manual occupations, particularly to stable during the downturn.

Living in a municipality with more than 40,000 inhabitants is associated with less chances of finding a stable or an unstable job in the recession period, suggesting that the crisis hits hardest in urbanized areas. Having dependent children implies higher hazard rates in both years and for both types of jobs, in line with Bover et al. (2002). The difference is especially strong in exits to stable jobs during the recession period. It therefore seems that those with dependent children workers search harder or reduce their job acceptance requirements more than others during the crisis. 


\section{Previous Job and Other Labour Market History Variables}

To interpret the coefficients of the labour market history variables, it should be noted that these variables may capture causal effects but also (time-persistent) heterogeneity. In fact, employers may also use this type of information as a signal to hire someone or not. The industry in which someone worked longest has different effects at different stages of the business cycle and on stable and unstable jobs. The crisis reduces the probability of finding a stable job most strongly in the construction sector. In 2005, an employee from the construction sector had a $20 \%$ higher probability of exiting to a stable than an otherwise similar unemployed worker in the services sector, but in 2009 , the difference changed to $4 \%$ lower. On the other hand, industrial workers had similar exit probabilities to a stable job as otherwise similar services workers in both periods. In contrast, the unemployed from the construction sector retained their higher exit rates to unstable jobs compared to the unemployed from the services sector. The unemployed from the manufacturing sector caught up in this respect during the crisis - in 2009, their exit rates to unstable jobs were similar to those of construction workers. Bover et al. (2002), considering a complete business cycle, find that hazard rates to any job in Spain are ordered as agriculture (highest), construction, services and manufacturing (lowest). Alba et al. (2012) find for 20002002 that workers from services have the highest chances find a new job, but not for recall. These studies do not show the effect of the crisis on the differences in the hazard rates across industries.

The larger the size of the firm where the unemployed had the previous job, the higher the reemployment hazards. Working at a larger company may signal a larger productivity to potential employers. On the other hand, larger companies more often recall workers, alternating between temporary contracts and temporary layoffs. Moreover, unemployment spells could be shorter in large firms because of the larger effectiveness of workers' representatives (Jimeno and Toharia, 1993). Alba et al. (2012) also found that the unemployed from larger firms have higher hazard rates, both for recalls and for new jobs. During the crisis, the size effects increase, perhaps because the probability of recall grows mostly for larger companies.

The type of former contract influences the duration of unemployment spells in different ways. The ordering of the type of contract from highest to lowest hazard rate in exits to stable jobs is: openended, on-call temporary, temporary, and permanent. It is the same in the two time periods. For exits to unstable jobs in 2005 it is: on-call temporary, temporary, open-ended and permanent. In 2009, the effec of the type of contract increase and the ordering changes to: on-call temporary, open-ended, temporary, and permanent. Thus workers with previous permanent contract, other things equal, have longer unemployment spells, and this pattern is further aggravated by the economic crisis. These results are largely in line with the existing literature. Alba et al. (2012) and Arranz et al. (2010) also found higher hazard rates in temporary and open-ended contracts.

García-Pérez and Muñoz (2011) find a pattern of high rotation for a group of workers with high exit rates from both temporary employment and from unemployment to temporary employment. Alba 
et al. (2012) support the hypothesis that in Spain firms and workers make strategic use of unemployment benefits, with consecutive fixed-term employment spells and unemployment benefits spells. Bover et al. (2002) find that fixed-term contracts raise the hazards into employment as well as unemployment. Moreover, employers tend to use temporary and especially open-ended contracts for seasonal adjustments. The work interruptions are covered either working in a different industry or by receiving unemployment benefits (Alba et al., 2012). Thus, the economic nature of open-ended contracts leads to more job rotation.

The duration of the former job has a negative and significant coefficient in all hazards, but its magnitude is much higher in the transitions to unstable jobs. For instance, in 2005 a one year longer contract duration was associated with a $1.8 \%(24.2 \%)$ smaller probability of an exit to a stable (unstable) job. If we interpret this variable as a proxy of the benefit entitlement period, this effect is similar to previous findings and reflect that longer benefit entitlements make the unemployed more selective in accepting jobs (Arranz and Muro, 2004), particularly secondary (unstable) jobs. The crisis reduces the magnitudes of the coefficients, suggesting that it makes the unemployed less selective.

The historical use of unemployment benefits has a negative sign in exits to stable jobs for both periods, implying that workers with less stable employment careers have fewer exit opportunities to stable jobs. This effect might be explained by the loss of skills while unemployed or may reflect timepersistent unobserved heterogeneity (Lockwood, 1991; Blanchard and Diamond 1994). The effect increases with the crisis, in line with the results of Arranz and Muro (2004) for unemployment durations of Spanish youth. The same covariate is not significant in the transition to unstable jobs.

The higher the part time coefficient in the previous job, the higher the exit probability to an unstable job. This could be because (keeping benefits and other variables constant) the negative utility of unemployment is higher for full time workers than for part-time employees.

\section{Unobserved heterogeneity}

In the single risk specifications, unobserved heterogeneity is significantly present according to likelihood ratio tests, and higher in the recession period (variance 1.35) than before that (variance 0.97). This is in line with the fact that the pool of workers who become unemployed is larger and more diverse in 2009. In the competing risks estimations, frailty is also significant in both periods. Moreover, the correlation between the two unobserved heterogeneity terms is significantly positive ${ }^{10}(0.68$ in 2005 and 0.73 in 2009), implying that someone who is likely to find a stable job also has better chances of getting an unstable job.

According to the estimated discrete distribution, most individuals (78\% in 2005 and $76 \%$ in 2009; Type 3) belong to a group in which both exit hazard rates are relatively low (15 to 18\% lower than

\footnotetext{
${ }^{10}$ The correlation between the unobserved heterogeneity terms in the competing risks model by type of contract is also positive, 0.16 in the 2005 sample and 0.85 in the 2009 sample.
} 
average for exits to stable jobs, 36 to $39 \%$ for unstable jobs). A very small group (3\% in the 2005 sample and 1\% in the 2009 sample; Type 2) has very high exit chances to a stable job; the third group has a high unstable job hazard (20\% in 2005 and 23\% in 2009; Type 1).

\section{Baseline Hazard Estimates}

Figure 6 shows the survival functions and hazards of the competing risk model for a benchmark person. They differ from Figures 1 and 2 since they control for heterogeneity entering through the covariates and the frailty term. The top panel shows, for example, that in the benchmark group in 2005, $65 \%$ would get a stable job within 1 year, and $61 \%$ would get an unstable job, so that the probability of finding any job (stable or unstable) would be $86 \%\left(\left(1-0.35^{*} 0.39\right) * 100 \%\right)$. In 2009 , the probabilities to find stable or unstable jobs have both fallen (by about $11 \%$ and $14 \%$-points respectively), so that the benchmark group's probability to find any job within a year has fallen to $75 \%$. Correspondingly, the median unemployment durations (assuming stable or unstable jobs are the only exits) increased from 7 to 11 months for stable jobs and from 8 to 13 months for unstable jobs.

The bottom panel shows the corresponding hazard rates. Since observed and unobserved heterogeneity are controlled for, the negative slopes can be interpreted as true negative state dependence (Heckman and Singer, 1984). This also explains the difference with Figure 2 which shows much stronger negative slopes since they do not eliminate negative duration dependence due to selection and observed and unobserved heterogeneity. The duration dependence is larger for stable than for unstable jobs, suggesting that unemployed workers originally looking for a primary job start looking for a secondary job when the unemployment spell lasts longer. Duration dependence is also stronger in 2005 than in 2009 (except in the right tail), possibly due to a negative stigma effect that makes employers reluctant to hire longer term unemployed before the crisis. This stigma disappears during the crisis when also more productive workers remain unemployed. This result is in line with a theoretical study of Lockwood (1991), arguing that negative duration dependence is weaker the higher the unemployment rate, whereas Blanchard and Diamond (1994) get the opposite result. Kalwij (2010), controlling for unobserved heterogeneity, finds no evidence in favour of either of these models. On the other hand, during the downturn employment becomes demand driven and the scarcity of job offers make individuals not to be able to find a job even although unemployment benefit is about to expire. 
Figure 6. Survival functions (top panel) and hazard rates (bottom panel) benchmark person for stable and unstable jobs; 2005 and 2009 samples; competing risks model.
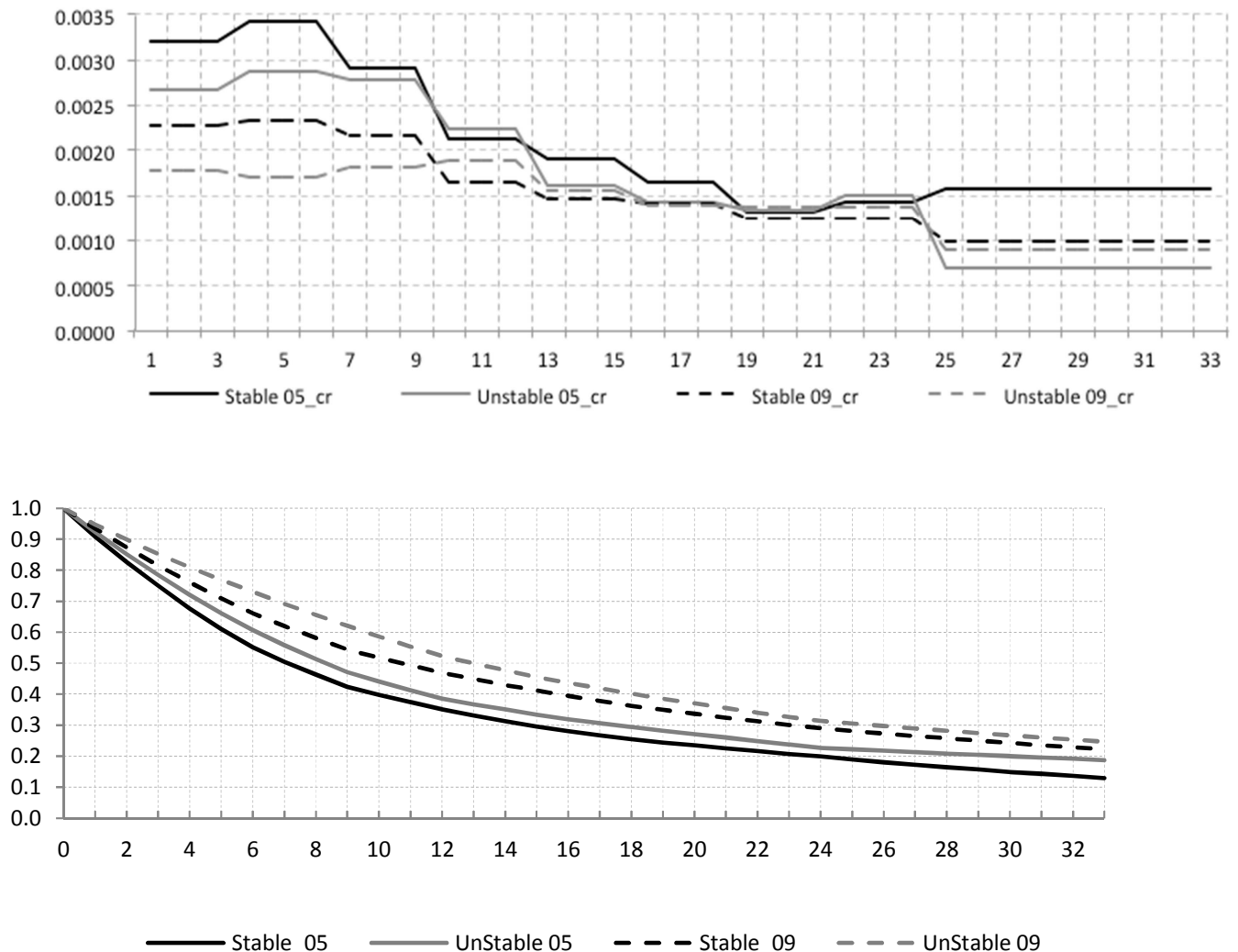

Source: Own elaboration.

Notes: Durations in months. Benchmark man: age group 35 - 39, medium skill level, non-manual occupation. services sector, municipality with more than 40.000 inhabitants, Spanish, without dependent children, previous contract temporary, at small business; average values of the other (continuous) variables.

Figure 7 compares the total exit rates (to a stable or an unstable job) and corresponding survival function for the same benchmark person according to the competing risks model and from the single risk model. The top panel shows that the survival probabilities according to the two models overlap in both time periods. The hazard to leave unemployment is higher after the spell has lasted for three months according to the single risk estimates than according to the competing risk model. The bottom panel confirms that the single risk model substantially overestimates the job exit rates after longer durations, both before and during the crisis. A plausible interpretation is that the single risk model is not able to capture all the (observed and unobserved) heterogeneity and therefore still contains spurious state dependence. This highlights the importance of using the richer competing risks model rather than the single risk specification. 
Figure 7. Survival functions (top) and hazard rates (bottom) benchmark person for exits to any job in single risk and competing risks models; 2005 and 2009 samples.
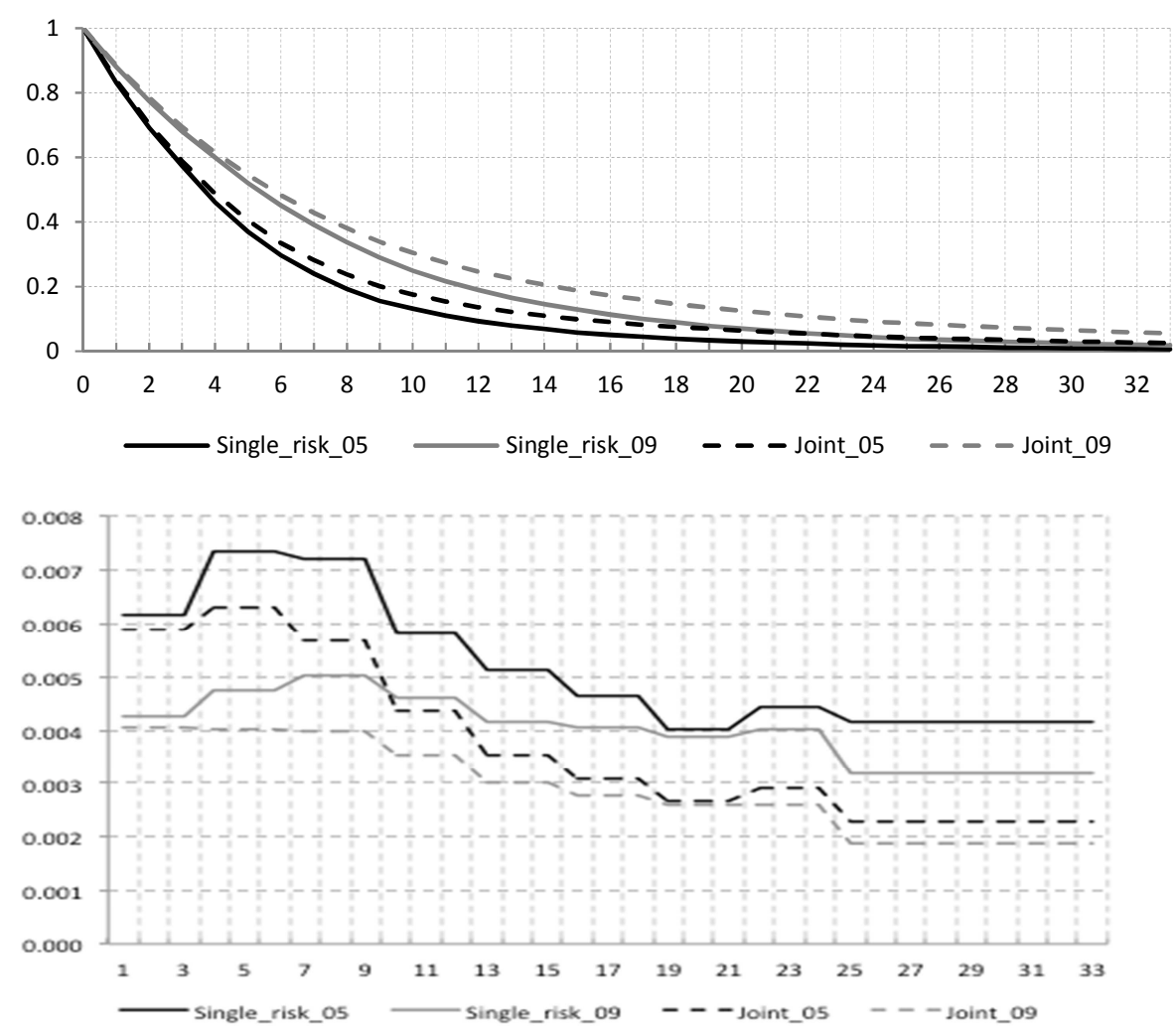

Source: Own elaboration. Notes: see Figure 6

\section{Sensitivity analysis}

Table 7 shows the results of the competing risks model in which the two types of exits are jobs with a permanent and jobs with a temporary contract. Many results are similar to those for the benchmark model, with permanent contracts corresponding to stable jobs and temporary contracts to unstable jobs, but there are also some substantial differences. For example, Table 7 shows that in both samples, unemployed workers from the construction sector have a substantially smaller probability to get a permanent contract than the unemployed from other sectors, whereas they are not less likely to find a stable job. Apparently permanent contracts are relatively rare in the construction sector but this does not mean that jobs are less stable there. Another difference concerns gender - Men have higher probabilities of stable as well as unstable job exits than comparable women, but Table 7 shows that this only works through temporary contracts.

In Tables 8 and 9, we compare the results for our benchmark definition of the distinction between stable and unstable jobs (more or less than 90 days) with the results based upon two alternative definitions using cut offs of 60 and 180 days. The model specification is the same as for the benchmark model (Table 4). Obviously, the proportions of exits to stable and unstable jobs change with the cut off. In 2005 and 2009, 43\% and 38\% of unemployment spells end in jobs that last more than 60 days and $20 \%$ and $21 \%$ in jobs lasting less than 60 days, respectively; $28 \%$ and $23 \%$ of unemployment 
spells end in jobs that last more than 180 days in 2005 and 2009, and 36\% end in jobs lasting less than 180 days in both samples.

Most of the effects of the explanatory variables on the re-employment hazards tend to be qualitatively similar for the three thresholds. But some coefficients change in size, significance, or even sign. For instance, the coefficient on the unemployment rate in the hazard to an unstable job becomes signficantly negative in the 2005 sample when the cut off is 180 days. This suggests that during the expansion period the chances to find a job that lasts between 90 and 180 days are particularly sensitive to the unemployment rate. Nevertheless, the qualitative conclusion remains unchanged that during the expansion period regional unemployment differences mainly influence the exit rates to primary (stable) jobs, while during the downturn the regional unemployment rate affects primary and secondary job finding rates in a similar way.

Differences in the influence of some explanatory variables over the re-employment probability for different job durations, specifically from 90 to 180 days would justify the split into three destination states. However, it would make the estimation problem more complex and computationally burdensome.

Table 10 shows the results of a competing risks model in which the shared frailty terms in the two hazards follow independent inverse Gaussian distributions. Comparing to the correlated competing risks model in Table 4 shows that all the coefficients on the covariates retain the same sign. For exits to unstable jobs the coefficients are rather similar, but for exits to stable jobs, there are more differences. For example, the coefficient on manufacturing that is positive and significant in Table 10 but insignificant in Table 4, both in the expansion and the recession period. Other substantial differences are found for some of the age parameters and the part time coefficient in the 2009 sample.

\section{Conclusions}

We have analysed transitions out of unemployment during an expansion (2005-2007) and during the recent recession (2009-2011), distinguishing exits to different types of jobs. We estimated a correlated competing risk model using a large administrative data set from the Spanish Social Security Administration. In line with the notion of a segmented labour market, we found large differences between the hazards to primary jobs (stable jobs, or jobs with a permanent contract) and the hazards to secondary jobs (unstable or temporary). Since the large majority of the new jobs are temporary, we focus on a competing risks model distinguishing stable and unstable jobs.

Comparing unemployment exits before and during the crisis, we find that the chances to find a job within the first twelve months are strongly reduced, and this is not compensated by higher hazards after the first twelve months. Exits to both stable and unstable jobs are much less likely during the crisis than in the expansion period during the first year of an unemployment spell. Negative duration 
dependence of the hazard is found particularly for stable jobs in the expansion period, but only until the unemployment benefit is about to expire.

Individuals who are most affected by the financial crisis tend to be males and young workers (1624), the age group 40-51, those living in regions with higher unemployment rates, the less qualified, working in manual occupations, individuals without family responsibilities, immigrants, and workers from the construction sector (particularly for stable job exits).

During the economic crisis, the comparative advantages of high skilled workers to find stable or unstable jobs seem to increase, suggesting that in the downturn high-qualified workers substitute lowqualified workers. Low skilled workers experience major problems finding jobs, suggesting that they require special attention from policymakers through, for example, active labour market policies.

We found that unemployed workers from temporary jobs experience higher re-employment probabilities than those from permanent jobs, but they also have higher entry rates of unemployment (Bover et al., 2002). Fixed-term contracts induce high job rotation and possible strategic use of unemployment benefits by employees and employers, in line with findings of Alba et al. (2012). For minimizing this strategic use, an experience-rating system could be implemented. With this system, we would also expect less incentives for the use of unstable jobs and a reduction of labour market duality. 


\section{Appendix A}

Figure 5: Survival Function estimates; exits from unemployment to temporary and permanent jobs

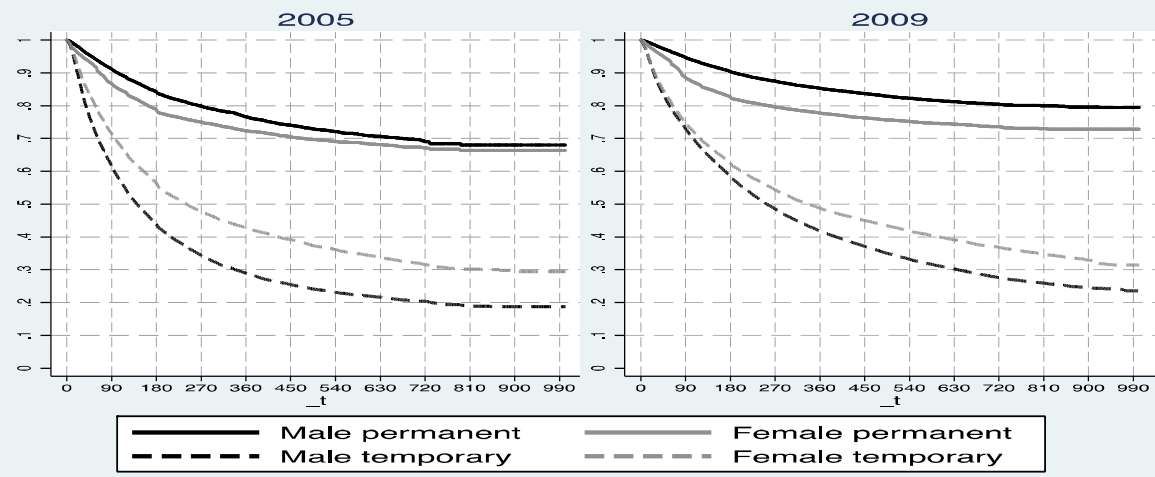

Source: Own elaboration from LWLS; Kaplan Meier estimates

Table 5 Sample selection

\begin{tabular}{lcc}
\multicolumn{1}{c}{ Filters } & \multicolumn{2}{c}{ Number of individuals } \\
\cline { 2 - 3 } & $\mathbf{2 0 0 5}$ sample & $\mathbf{2 0 0 9}$ sample \\
\hline Number of individuals starting any unemployment benefit spell in the year of reference & 100,250 & 188,448 \\
Drop individuals with lack of relevant information & 480 & 2,296 \\
Drop Individuals with any disability pension in the observation period & 974 & 1,737 \\
Drop individuals from agriculture industry & 9,997 & 23,016 \\
After merging consecutive unemployment spells, drop spells starting before the year of & 6,741 & 14,893 \\
reference & 2,876 & 13,749 \\
Drop overlapped spells and incidences & 2,619 & 6,874 \\
Drop spells because of missing information of former type of contract & 746 & 1,397 \\
Drop individuals with any degree of disability & $\mathbf{7 5 , 8 1 7}$ & $\mathbf{1 2 4 , 4 8 6}$ \\
Final sample (number of individuals) & &
\end{tabular}

Source: Own elaboration from 2005-2007 LWLS and 2009-2011 LWLS.

Table 6: Definitions of explanatory variables

\begin{tabular}{|c|c|}
\hline \multicolumn{2}{|r|}{ Individual characteristics } \\
\hline Male & 1 if male \\
\hline Age & $\begin{array}{l}\text { Dummies for ages } 16-19 ; 20-24 ; 25-29 ; 30-34 ; 35-39 ; 40-44 ; 45-51 ; 52-60 \text {; older } 61 \text { (time- } \\
\text { varying) }\end{array}$ \\
\hline Spanish-speaking immigrants & 1 if immigrant from a Spanish-speaking country \\
\hline Non-Spanish speaking immigrants & 1 if immigrant from a non-Spanish-speaking country \\
\hline Dummy dependent children & $\begin{array}{l}1 \text { if the individual has children younger than } 25 \text { years old or of any age with a degree of } \\
\text { disability of at least } 33 \% \text {, living in a common house, with income lower than } € 8,000 \text { (in } \\
2013 \text { ) and not filing an IRPF tax return }\end{array}$ \\
\hline High skilled & $\begin{array}{l}\text { In non-manual occupations: engineers, graduates, senior executives, technical engineers } \\
\text { and technical assistants; In manual occupations: first and second officers }\end{array}$ \\
\hline Medium skilled & $\begin{array}{l}\text { In non -manual occupations: administration officers, head foremen and non-qualified } \\
\text { assistants; In manual occupations: third officers and specialists }\end{array}$ \\
\hline Low skilled & $\begin{array}{l}\text { In non-manual occupations: administrative assistants and subalterns; in manual } \\
\text { occupations: peons, etc. }\end{array}$ \\
\hline Non-manual occupation & 1 if non-manual occupation \\
\hline & Macroeconomic variables \\
\hline Unemployment rate & $\begin{array}{l}\text { Quarterly unemployment rate by gender and region (time-varying); source: Economically } \\
\text { Active Population Survey (EPA) }\end{array}$ \\
\hline Inhabitants $>40,000$ & $\begin{array}{l}1 \text { if the number of inhabitants of the municipality where the individual is living is greater } \\
\text { than } 40.000\end{array}$ \\
\hline Sector of activity & $\begin{array}{l}\text { Dummies for sector of activity in which the individual has been working the longest: } \\
\text { Manufacturing, construction or services }\end{array}$ \\
\hline
\end{tabular}


Table 6, continued

Previous job and labour market history variables

\begin{tabular}{ll}
\hline Historical use of Unemployment & $\begin{array}{l}\text { Number of days receiving unemployment benefits divided by the sum of days working } \\
\text { and days receiving unemployment benefits }\end{array}$ \\
$\begin{array}{l}\text { Duration of previous job } \\
\text { Type of previous contract }\end{array}$ & Duration of former job (in days) \\
Size of the firm in previous job & Dummies for permanent, on-call temporary, temporary, and open-ended \\
Part time coefficient in former job & Dummies for 0 (self-employed, missing), 1-19, 10-19,20-49,50-249, $>250$ \\
\hline
\end{tabular}

Source: Own elaboration from LWLS and INE.

Table 7: Estimation results of models with correlated competing risks (exits to temporary and permanent jobs); 2005 and 2009 samples

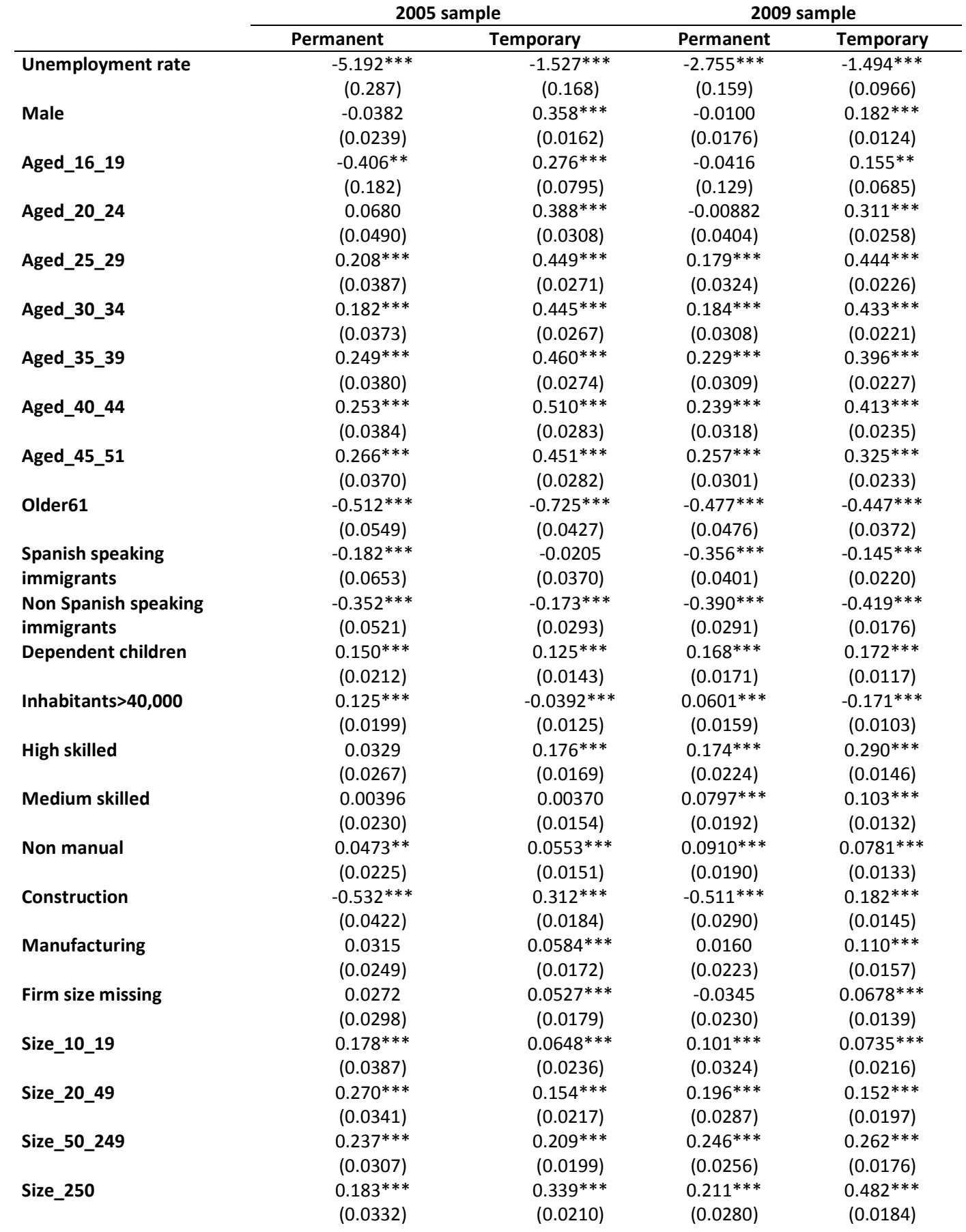


Table 7, continued

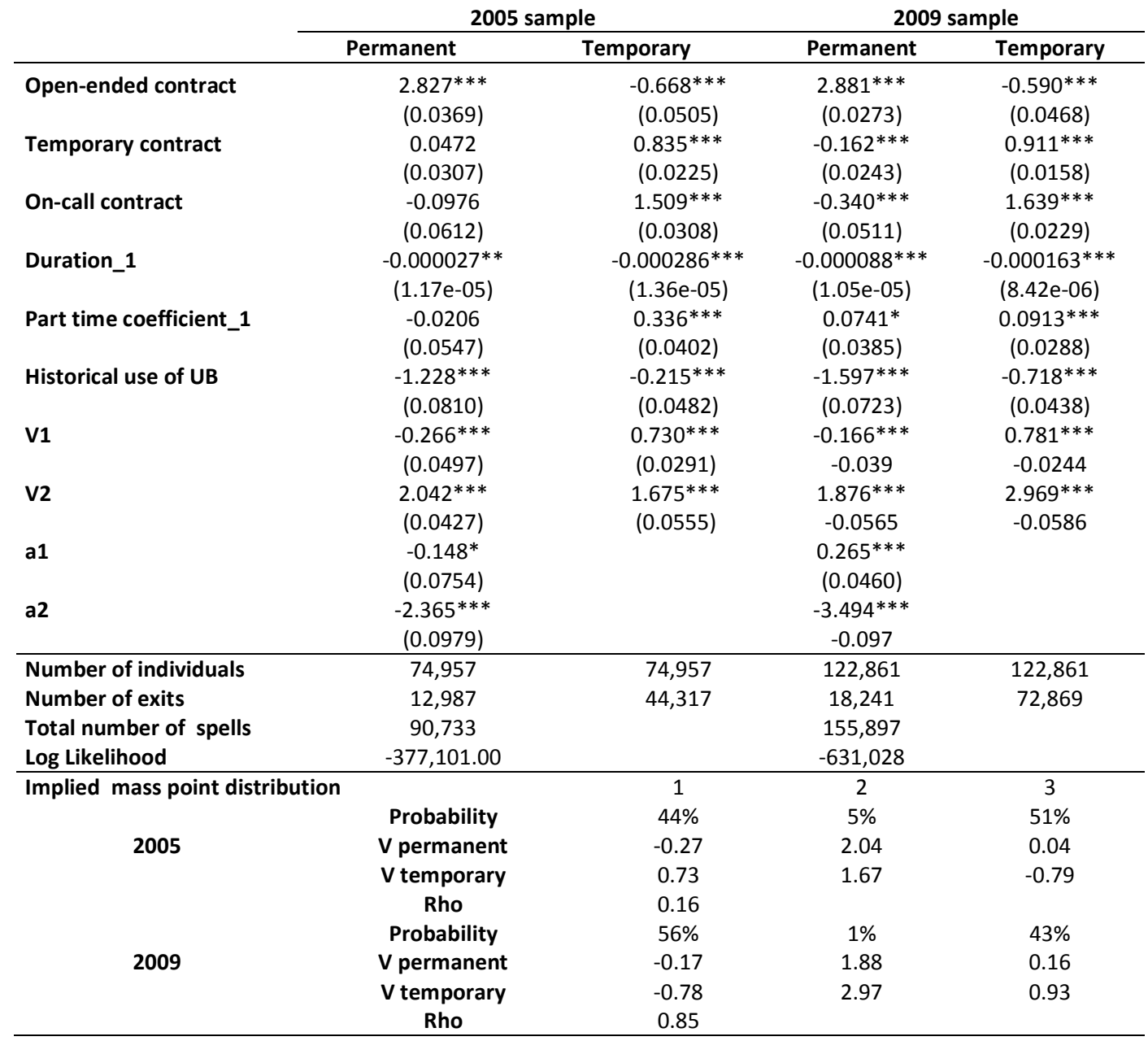

Notes: see Table 4. $E[V]=0$ for both samples and two destination states.

Table 8: Estimation results of models with correlated competing risks for definitions of stable and unstable jobs according to three thresholds: 60,90 and 180 days. 2005 sample.

\begin{tabular}{lcccccc} 
& Stable 60 & Stable 90 & Stable 180 & Unstable 60 & Unstable 90 & Unstable 180 \\
\hline & & & & & & \\
Unemployment rate & $-3.648^{* * *}$ & $-3.781^{* * *}$ & $-3.335^{* * *}$ & 0.0791 & -0.238 & $-1.538^{* * *}$ \\
& $(0.164)$ & $(0.174)$ & $(0.202)$ & $(0.238)$ & $(0.220)$ & $(0.195)$ \\
Male & $0.196^{* * *}$ & $0.176^{* * *}$ & $0.194^{* * *}$ & $0.350^{* * *}$ & $0.329^{* * *}$ & $0.268^{* * *}$ \\
& $(0.0145)$ & $(0.0150)$ & $(0.0174)$ & $(0.0236)$ & $(0.0215)$ & $(0.0188)$ \\
Aged_16_19 & 0.0909 & 0.000839 & $-0.201^{*}$ & $0.206^{*}$ & $0.295^{* * *}$ & $0.333^{* * *}$ \\
& $(0.0829)$ & $(0.0923)$ & $(0.120)$ & $(0.114)$ & $(0.106)$ & $(0.0926)$ \\
Aged_20_24 & $0.281^{* * *}$ & $0.249^{* * *}$ & $0.188^{* * *}$ & $0.320^{* * *}$ & $0.340^{* * *}$ & $0.359^{* * *}$ \\
& $(0.0284)$ & $(0.0297)$ & $(0.0348)$ & $(0.0445)$ & $(0.0409)$ & $(0.0360)$ \\
Aged_25_29 & $0.387^{* * *}$ & $0.359^{* * *}$ & $0.336^{* * *}$ & $0.339^{* * *}$ & $0.343^{* * *}$ & $0.375^{* * *}$ \\
& $(0.0241)$ & $(0.0250)$ & $(0.0288)$ & $(0.0392)$ & $(0.0356)$ & $(0.0311)$ \\
Aged_30_34 & $0.380^{* * *}$ & $0.358^{* * *}$ & $0.345^{* * *}$ & $0.328^{* * *}$ & $0.331^{* * *}$ & $0.352^{* * *}$ \\
& $(0.0236)$ & $(0.0244)$ & $(0.0281)$ & $(0.0388)$ & $(0.0352)$ & $(0.0307)$ \\
Aged_35_39 & $0.401^{* * *}$ & $0.372^{* * *}$ & $0.375^{* * *}$ & $0.352^{* * *}$ & $0.378^{* * *}$ & $0.379^{* * *}$ \\
& $(0.0242)$ & $(0.0251)$ & $(0.0288)$ & $(0.0398)$ & $(0.0361)$ & $(0.0315)$ \\
Aged_40_44 & $0.412^{* * *}$ & $0.387^{* * *}$ & $0.389^{* * *}$ & $0.430^{* * *}$ & $0.436^{* * *}$ & $0.424^{* * *}$ \\
& $(0.0250)$ & $(0.0257)$ & $(0.0295)$ & $(0.0408)$ & $(0.0371)$ & $(0.0325)$ \\
Aged_45_51 & $0.384^{* * *}$ & $0.369^{* * *}$ & $0.363^{* * *}$ & $0.384^{* * *}$ & $0.372^{* * *}$ & $0.375^{* * *}$ \\
& $(0.0246)$ & $(0.0254)$ & $(0.0291)$ & $(0.0406)$ & $(0.0370)$ & $(0.0322)$ \\
Older61 & $-0.627^{* * *}$ & $-0.605^{* * *}$ & $-0.635^{* * *}$ & $-0.722^{* * *}$ & $-0.667^{* * *}$ & $-0.624 * * *$ \\
& $(0.0369)$ & $(0.0385)$ & $(0.0444)$ & $(0.0639)$ & $(0.0582)$ & $(0.0492)$
\end{tabular}


Table 8, continued

\begin{tabular}{|c|c|c|c|c|c|c|}
\hline & Stable 60 & Stable 90 & Stable 180 & Unstable 60 & Unstable 90 & Unstable 180 \\
\hline Spanish speaking & $-0.101 * * *$ & $-0.105 * * *$ & $-0.192 * * *$ & 0.0668 & 0.0593 & $0.0819^{*}$ \\
\hline immigrants & $(0.0350)$ & $(0.0369)$ & $(0.0446)$ & $(0.0535)$ & $(0.0497)$ & $(0.0435)$ \\
\hline Non Spanish speaking & $-0.225 * * *$ & $-0.224 * * *$ & $-0.249 * * *$ & $-0.196 * * *$ & $-0.162 * * *$ & $-0.169 * * *$ \\
\hline immigrants & $(0.0275)$ & $(0.0290)$ & $(0.0342)$ & $(0.0434)$ & $(0.0405)$ & $(0.0357)$ \\
\hline \multirow[t]{2}{*}{ Dependent children } & $0.147^{* * *}$ & $0.138 * * *$ & $0.151^{* * *}$ & $0.0963 * * *$ & $0.0941 * * *$ & $0.0922 * * *$ \\
\hline & $(0.0127)$ & $(0.0131)$ & $(0.0151)$ & $(0.0211)$ & $(0.0191)$ & $(0.0168)$ \\
\hline \multirow[t]{2}{*}{ Inhabitants>40,000 } & -0.00268 & -0.000919 & -0.00529 & 0.0124 & 0.00258 & 0.00785 \\
\hline & $(0.0114)$ & (0.0119) & $(0.0138)$ & $(0.0184)$ & (0.0168) & $(0.0148)$ \\
\hline \multirow[t]{2}{*}{ High skilled } & $0.172 * * *$ & $0.180 * * *$ & $0.224 * * *$ & 0.0174 & $0.0427^{*}$ & $0.0451 * *$ \\
\hline & $(0.0154)$ & $(0.0160)$ & $(0.0185)$ & $(0.0244)$ & $(0.0224)$ & (0.0198) \\
\hline \multirow[t]{2}{*}{ Medium skilled } & 0.0229 & $0.0259 *$ & $0.0345 * *$ & $-0.0626 * * *$ & $-0.0393^{*}$ & -0.0258 \\
\hline & $(0.0140)$ & $(0.0146)$ & $(0.0169)$ & $(0.0221)$ & $(0.0203)$ & $(0.0180)$ \\
\hline \multirow[t]{2}{*}{ Non-manual } & $0.0528 * * *$ & $0.0693 * * *$ & $0.111^{* * *}$ & -0.00743 & -0.0134 & -0.0265 \\
\hline & $(0.0135)$ & $(0.0140)$ & $(0.0163)$ & (0.0219) & $(0.0201)$ & $(0.0176)$ \\
\hline \multirow[t]{2}{*}{ Construction } & $0.206 * * *$ & $0.184^{* * *}$ & $0.156 * * *$ & $0.212^{* * *}$ & $0.211^{* * *}$ & $0.230 * * *$ \\
\hline & $(0.0172)$ & $(0.0180)$ & $(0.0212)$ & $(0.0274)$ & $(0.0250)$ & $(0.0221)$ \\
\hline \multirow[t]{2}{*}{ Manufacturing } & $0.0566 * * *$ & $0.0273^{*}$ & $-0.0536 * * *$ & $0.0735 * * *$ & $0.123 * * *$ & $0.173 * * *$ \\
\hline & $(0.0153)$ & (0.0159) & $(0.0186)$ & $(0.0250)$ & $(0.0227)$ & (0.0198) \\
\hline \multirow[t]{2}{*}{ Firm size missing } & 0.0176 & -0.0110 & $-0.0626 * * *$ & $0.138 * * *$ & $0.154 * * *$ & $0.154 * * *$ \\
\hline & $(0.0166)$ & (0.0173) & $(0.0203)$ & $(0.0266)$ & $(0.0244)$ & $(0.0213)$ \\
\hline \multirow[t]{2}{*}{ Size_10_19 } & $0.0952 * * *$ & $0.0830 * * *$ & $0.0751^{* * *}$ & $0.117^{* * *}$ & $0.117 * * *$ & $0.120 * * *$ \\
\hline & $(0.0217)$ & $(0.0226)$ & $(0.0263)$ & $(0.0352)$ & (0.0323) & (0.0283) \\
\hline \multirow[t]{2}{*}{ Size_20_49 } & $0.185^{* * *}$ & $0.164 * * *$ & $0.154^{* * *}$ & $0.195^{* * *}$ & $0.223 * * *$ & $0.224 * * *$ \\
\hline & (0.0196) & $(0.0204)$ & $(0.0236)$ & $(0.0324)$ & $(0.0296)$ & (0.0258) \\
\hline \multirow[t]{2}{*}{ Size_50_249 } & $0.212^{* * *}$ & $0.184 * * *$ & $0.173 * * *$ & $0.278 * * *$ & $0.297 * * *$ & $0.281 * * *$ \\
\hline & (0.0179) & $(0.0186)$ & $(0.0214)$ & $(0.0293)$ & $(0.0268)$ & $(0.0234)$ \\
\hline \multirow[t]{2}{*}{ Size_250 } & $0.228 * * *$ & $0.198 * * *$ & $0.173 * * *$ & $0.467 * * *$ & $0.442 * * *$ & $0.398 * * *$ \\
\hline & $(0.0192)$ & (0.0199) & $(0.0230)$ & $(0.0306)$ & (0.0279) & (0.0245) \\
\hline \multirow[t]{2}{*}{ Open-ended contract } & $1.747^{* * *}$ & $1.775 * * *$ & $1.870 * * *$ & $0.534 * * *$ & $0.663 * * *$ & $0.888 * * *$ \\
\hline & $(0.0263)$ & $(0.0265)$ & (0.0295) & $(0.0534)$ & $(0.0486)$ & $(0.0412)$ \\
\hline \multirow[t]{2}{*}{ Temporary contract } & $0.586 * * *$ & $0.523 * * *$ & $0.424 * * *$ & $0.642 * * *$ & $0.674 * * *$ & $0.728 * * *$ \\
\hline & $(0.0191)$ & $(0.0193)$ & $(0.0217)$ & $(0.0362)$ & $(0.0330)$ & (0.0285) \\
\hline \multirow[t]{2}{*}{ On-call contract } & $1.022 * * *$ & $0.927 * * *$ & $0.791 * * *$ & $1.393 * * *$ & $1.386 * * *$ & $1.391 * * *$ \\
\hline & $(0.0285)$ & $(0.0292)$ & (0.0339) & $(0.0464)$ & $(0.0422)$ & $(0.0370)$ \\
\hline \multirow[t]{2}{*}{ Duration_1 } & $-0.000075^{* * *}$ & $-0.000055^{* * *}$ & -0.000006 & $-0.000938 * * *$ & $-0.000766 * * *$ & $-0.000595 * * *$ \\
\hline & (8.48e-06) & $(8.42 \mathrm{e}-06)$ & $(8.53 e-06)$ & (3.28e-05) & (2.79e-05) & (2.15e-05) \\
\hline \multirow[t]{2}{*}{ Part time coefte_1 } & $0.0633^{*}$ & -0.0224 & $-0.200 * * *$ & $0.779 * * *$ & $0.809 * * *$ & $0.739 * * *$ \\
\hline & $(0.0347)$ & $(0.0357)$ & $(0.0400)$ & $(0.0624)$ & $(0.0573)$ & $(0.0496)$ \\
\hline \multirow[t]{2}{*}{ Historical use of UB } & $-0.586 * * *$ & $-0.638 * * *$ & $-0.845 * * *$ & -0.102 & $-0.106^{*}$ & $-0.104^{*}$ \\
\hline & $(0.0447)$ & $(0.0467)$ & $(0.0550)$ & $(0.0690)$ & $(0.0622)$ & $(0.0548)$ \\
\hline \multirow{3}{*}{$\begin{array}{l}\text { Number of } \\
\text { individuals } \\
\text { Number of exits } \\
\text { Total number of } \\
\text { spells }\end{array}$} & 75,817 & 75,817 & 75,817 & 75,817 & 75,817 & 75,817 \\
\hline & 39,634 & 34,918 & 25,707 & 18,801 & 23,517 & 32,728 \\
\hline & 91,787 & 91,787 & 91,787 & 91,787 & 91,787 & 91,787 \\
\hline Log Likelihood & $-97,621$ & $-398,732$ & $-73,004$ & $-97,621$ & $-398,732$ & $-73,004$ \\
\hline Implied mass point dis & ibution & 1 & 2 & 3 & $\mathrm{E}[\mathrm{V}]$ & \\
\hline & Probability & $36 \%$ & $2 \%$ & $62 \%$ & & \\
\hline 60 days & V stable & 0.46 & 2.14 & -0.34 & 0 & \\
\hline & V unstable & 1.24 & 2.74 & -0.81 & 0 & \\
\hline & Rho= & 0.96 & & & & \\
\hline & Probability & $20 \%$ & $3 \%$ & $77 \%$ & & \\
\hline 180 days & V stable & -0.14 & 2.34 & -0.04 & 0 & \\
\hline & V unstable & 1.55 & 0.84 & -0.44 & 0 & \\
\hline & Rho= & 0.07 & & & & \\
\hline
\end{tabular}

Notes: see Table 4. 
Table 9: Estimation results of models with correlated competing risks for definitions of stable and unstable jobs according to three thresholds: 60, 90 and 180 days. 2009 sample.

\begin{tabular}{|c|c|c|c|c|c|c|}
\hline & Stable 60 days & Stable 90 days & Stable 180 & Unstable 60 & Unstable 90 & Unstable 180 \\
\hline Unemployment rate & $\begin{array}{c}-1.698^{* * *} \\
(0.0865)\end{array}$ & $\begin{array}{c}-1.815^{* * *} \\
(0.0921)\end{array}$ & $\begin{array}{c}-2.012^{* * *} \\
(0.110)\end{array}$ & $\begin{array}{c}-1.553^{* * *} \\
(0.131)\end{array}$ & $\begin{array}{c}-1.470 * * * \\
(0.120)\end{array}$ & $\begin{array}{c}-1.463^{* * *} \\
(0.105)\end{array}$ \\
\hline Male & $\begin{array}{l}0.119 * * * \\
(0.0107)\end{array}$ & $\begin{array}{l}0.112 * * * \\
(0.0113)\end{array}$ & $\begin{array}{l}0.105^{* * *} \\
(0.0130)\end{array}$ & $\begin{array}{l}0.128^{* * *} \\
(0.0169)\end{array}$ & $\begin{array}{l}0.125 * * * \\
(0.0155)\end{array}$ & $\begin{array}{l}0.113^{* * *} \\
(0.0136)\end{array}$ \\
\hline Aged_16_19 & $\begin{array}{c}-0.102 \\
(0.0808)\end{array}$ & $\begin{array}{c}-0.108 \\
(0.0874)\end{array}$ & $\begin{array}{l}-0.186^{*} \\
(0.112)\end{array}$ & $\begin{array}{c}0.208^{* *} \\
(0.101)\end{array}$ & $\begin{array}{c}0.169 * \\
(0.0934)\end{array}$ & $\begin{array}{c}0.138^{*} \\
(0.0823)\end{array}$ \\
\hline Aged_20_24 & $\begin{array}{l}0.121 * * * \\
(0.0233)\end{array}$ & $\begin{array}{c}0.0972 * * * \\
(0.0250)\end{array}$ & $\begin{array}{c}0.0344 \\
(0.0308)\end{array}$ & $\begin{array}{r}0.273 * * * \\
(0.0349)\end{array}$ & $\begin{array}{r}0.277 * * * \\
(0.0319)\end{array}$ & $\begin{array}{l}0.266 * * * \\
(0.0278)\end{array}$ \\
\hline Aged_25_29 & $\begin{array}{c}0.278 * * * \\
(0.0193)\end{array}$ & $\begin{array}{c}0.256 * * * \\
(0.0205)\end{array}$ & $\begin{array}{l}0.239 * * * \\
(0.0242)\end{array}$ & $\begin{array}{r}0.395 * * * \\
(0.0300)\end{array}$ & $\begin{array}{l}0.402 * * * \\
(0.0274)\end{array}$ & $\begin{array}{r}0.377 * * * \\
(0.0238)\end{array}$ \\
\hline Aged_30_34 & $\begin{array}{l}0.303 * * * \\
(0.0184)\end{array}$ & $\begin{array}{l}0.294 * * * \\
(0.0196)\end{array}$ & $\begin{array}{l}0.299 * * * \\
(0.0231)\end{array}$ & $\begin{array}{l}0.373 * * * \\
(0.0290)\end{array}$ & $\begin{array}{l}0.368 * * * \\
(0.0265)\end{array}$ & $\begin{array}{l}0.345^{* * *} \\
(0.0230)\end{array}$ \\
\hline Aged_35_39 & $\begin{array}{l}0.293 * * * \\
(0.0187)\end{array}$ & $\begin{array}{l}0.295^{* * *} \\
(0.0198)\end{array}$ & $\begin{array}{l}0.306 * * * \\
(0.0234)\end{array}$ & $\begin{array}{l}0.345 * * * \\
(0.0296)\end{array}$ & $\begin{array}{l}0.330 * * * \\
(0.0271)\end{array}$ & $\begin{array}{l}0.318^{* * *} \\
(0.0235)\end{array}$ \\
\hline Aged_40_44 & $\begin{array}{l}0.295 * * * \\
(0.0194)\end{array}$ & $\begin{array}{l}0.295 * * * \\
(0.0207)\end{array}$ & $\begin{array}{l}0.329 * * * \\
(0.0241)\end{array}$ & $\begin{array}{l}0.362 * * * \\
(0.0306)\end{array}$ & $\begin{array}{l}0.341 * * * \\
(0.0280)\end{array}$ & $\begin{array}{l}0.309 * * * \\
(0.0243)\end{array}$ \\
\hline Aged_45_51 & $\begin{array}{l}0.273 * * * \\
(0.0189)\end{array}$ & $\begin{array}{l}0.279 * * * \\
(0.0201)\end{array}$ & $\begin{array}{l}0.304 * * * \\
(0.0235)\end{array}$ & $\begin{array}{r}0.305 * * * \\
(0.0301)\end{array}$ & $\begin{array}{r}0.287 * * * \\
(0.0275)\end{array}$ & $\begin{array}{l}0.272^{* * *} \\
(0.0238)\end{array}$ \\
\hline Older61 & $\begin{array}{c}-0.512 * * * \\
(0.0297)\end{array}$ & $\begin{array}{c}-0.491 * * * \\
(0.0312)\end{array}$ & $\begin{array}{c}-0.467^{* * *} \\
(0.0348)\end{array}$ & $\begin{array}{c}-0.566 * * * \\
(0.0504)\end{array}$ & $\begin{array}{c}-0.587^{* * *} \\
(0.0458)\end{array}$ & $\begin{array}{c}-0.571 * * * \\
(0.0389)\end{array}$ \\
\hline $\begin{array}{l}\text { Spanish speaking } \\
\text { immigrants }\end{array}$ & $\begin{array}{c}-0.296 * * * \\
(0.0214)\end{array}$ & $\begin{array}{c}-0.326^{* * *} \\
(0.0232)\end{array}$ & $\begin{array}{c}-0.413^{* * *} \\
(0.0288)\end{array}$ & $\begin{array}{l}-0.00455 \\
(0.0290)\end{array}$ & $\begin{array}{l}-0.0327 \\
(0.0268)\end{array}$ & $\begin{array}{c}-0.0541^{* *} \\
(0.0236)\end{array}$ \\
\hline $\begin{array}{l}\text { Non Spanish speaking } \\
\text { immigrants }\end{array}$ & $\begin{array}{c}-0.428 * * * \\
(0.0163)\end{array}$ & $\begin{array}{c}-0.426 * * * \\
(0.0174)\end{array}$ & $\begin{array}{c}-0.439 * * * \\
(0.0211)\end{array}$ & $\begin{array}{c}-0.418^{* * *} \\
(0.0241)\end{array}$ & $\begin{array}{c}-0.413 * * * \\
(0.0220)\end{array}$ & $\begin{array}{c}-0.403 * * * \\
(0.0192)\end{array}$ \\
\hline Dependent children & $\begin{array}{c}0.172^{* * *} \\
(0.0101)\end{array}$ & $\begin{array}{l}0.162 * * * \\
(0.0107)\end{array}$ & $\begin{array}{l}0.148 * * * \\
(0.0125)\end{array}$ & $\begin{array}{l}0.114^{* * *} \\
(0.0159)\end{array}$ & $\begin{array}{c}0.133^{* * *} \\
(0.0146)\end{array}$ & $\begin{array}{l}0.145^{* * *} \\
(0.0128)\end{array}$ \\
\hline Inhabitants $>40,000$ & $\begin{array}{l}-0.130 * * * \\
(0.00906)\end{array}$ & $\begin{array}{l}-0.120 * * * \\
(0.00968)\end{array}$ & $\begin{array}{c}-0.0995 * * * \\
(0.0114)\end{array}$ & $\begin{array}{c}-0.0858^{* * *} \\
(0.0140)\end{array}$ & $\begin{array}{c}-0.113^{* * *} \\
(0.0128)\end{array}$ & $\begin{array}{c}-0.127 * * * \\
(0.0113)\end{array}$ \\
\hline High skilled & $\begin{array}{c}0.267 * * * \\
(0.0131)\end{array}$ & $\begin{array}{l}0.278 * * * \\
(0.0140)\end{array}$ & $\begin{array}{l}0.334^{* * *} \\
(0.0162)\end{array}$ & $\begin{array}{r}0.165^{* * *} \\
(0.0199)\end{array}$ & $\begin{array}{l}0.175^{* * *} \\
(0.0183)\end{array}$ & $\begin{array}{l}0.163^{* * *} \\
(0.0161)\end{array}$ \\
\hline Medium skilled & $\begin{array}{c}0.0844 * * * \\
(0.0117)\end{array}$ & $\begin{array}{c}0.0887 * * * \\
(0.0125)\end{array}$ & $\begin{array}{l}0.107 * * * \\
(0.0145)\end{array}$ & $\begin{array}{c}0.0781 * * * \\
(0.0177)\end{array}$ & $\begin{array}{c}0.0809 * * * \\
(0.0163)\end{array}$ & $\begin{array}{c}0.0717^{* * *} \\
(0.0143)\end{array}$ \\
\hline Non-manual & $\begin{array}{c}0.0877^{* * *} \\
(0.0115)\end{array}$ & $\begin{array}{l}0.102 * * * \\
(0.0123)\end{array}$ & $\begin{array}{l}0.161^{* * *} \\
(0.0144)\end{array}$ & $\begin{array}{l}0.0406 * * \\
(0.0181)\end{array}$ & $\begin{array}{l}0.0323^{*} \\
(0.0166)\end{array}$ & $\begin{array}{l}0.00897 \\
(0.0145)\end{array}$ \\
\hline Construction & $\begin{array}{c}0.0200 \\
(0.0131)\end{array}$ & $\begin{array}{c}-0.0436 * * * \\
(0.0141)\end{array}$ & $\begin{array}{c}-0.183^{* * *} \\
(0.0174)\end{array}$ & $\begin{array}{r}0.201 * * * \\
(0.0199)\end{array}$ & $\begin{array}{r}0.246 * * * \\
(0.0182)\end{array}$ & $\begin{array}{l}0.248 * * * \\
(0.0160)\end{array}$ \\
\hline Manufacturing & $\begin{array}{l}0.0327^{* *} \\
(0.0134)\end{array}$ & $\begin{array}{l}-0.0115 \\
(0.0144)\end{array}$ & $\begin{array}{c}-0.0703 * * * \\
(0.0168)\end{array}$ & $\begin{array}{l}0.178 * * * \\
(0.0213)\end{array}$ & $\begin{array}{r}0.215^{* * *} \\
(0.0194)\end{array}$ & $\begin{array}{l}0.216 * * * \\
(0.0170)\end{array}$ \\
\hline Firm size missing & $\begin{array}{l}-0.0200 \\
(0.0127)\end{array}$ & $\begin{array}{c}-0.0414 * * * \\
(0.0135)\end{array}$ & $\begin{array}{c}-0.0965 * * * \\
(0.0162)\end{array}$ & $\begin{array}{r}0.168^{* * *} \\
(0.0197)\end{array}$ & $\begin{array}{c}0.160 * * * \\
(0.0179)\end{array}$ & $\begin{array}{l}0.149 * * * \\
(0.0156)\end{array}$ \\
\hline Size_10_19 & $\begin{array}{c}0.0625^{* * *} \\
(0.0191)\end{array}$ & $\begin{array}{l}0.0479 * * \\
(0.0205)\end{array}$ & $\begin{array}{c}0.0487 * * \\
(0.0235)\end{array}$ & $\begin{array}{l}0.107 * * * \\
(0.0305)\end{array}$ & $\begin{array}{c}0.104 * * * \\
(0.0277)\end{array}$ & $\begin{array}{c}0.0892^{* * * *} \\
(0.0241)\end{array}$ \\
\hline Size_20_49 & $\begin{array}{l}0.109 * * * \\
(0.0174)\end{array}$ & $\begin{array}{l}0.108 * * * \\
(0.0184)\end{array}$ & $\begin{array}{c}0.0998 * * * \\
(0.0217)\end{array}$ & $\begin{array}{r}0.227 * * * \\
(0.0272)\end{array}$ & $\begin{array}{c}0.208 * * * \\
(0.0249)\end{array}$ & $\begin{array}{c}0.187 * * * \\
(0.0217)\end{array}$ \\
\hline Size_50_249 & $\begin{array}{l}0.204 * * * \\
(0.0153)\end{array}$ & $\begin{array}{l}0.204 * * * \\
(0.0162)\end{array}$ & $\begin{array}{c}0.191 * * * \\
(0.0189)\end{array}$ & $\begin{array}{r}0.346 * * * \\
(0.0242)\end{array}$ & $\begin{array}{r}0.315 * * * \\
(0.0222)\end{array}$ & $\begin{array}{l}0.291 * * * \\
(0.0193)\end{array}$ \\
\hline Size_250 & $\begin{array}{c}0.306 * * * \\
(0.0162)\end{array}$ & $\begin{array}{l}0.304 * * * \\
(0.0171)\end{array}$ & $\begin{array}{l}0.294 * * * \\
(0.0198)\end{array}$ & $\begin{array}{l}0.538 * * * \\
(0.0251)\end{array}$ & $\begin{array}{l}0.511^{* * *} \\
(0.0230)\end{array}$ & $\begin{array}{l}0.465^{* * *} \\
(0.0202)\end{array}$ \\
\hline Open-ended contract & $\begin{array}{l}1.932 * * * \\
(0.0196)\end{array}$ & $\begin{array}{l}1.975 * * * \\
(0.0204)\end{array}$ & $\begin{array}{l}2.037 * * * \\
(0.0224)\end{array}$ & $\begin{array}{l}1.021 * * * \\
(0.0393)\end{array}$ & $\begin{array}{l}1.030 * * * \\
(0.0356)\end{array}$ & $\begin{array}{l}1.169 * * * \\
(0.0302)\end{array}$ \\
\hline Temporary contract & $\begin{array}{c}0.528^{* * *} \\
(0.0134)\end{array}$ & $\begin{array}{c}0.483 * * * \\
(0.0141)\end{array}$ & $\begin{array}{c}0.368 * * * \\
(0.0161)\end{array}$ & $\begin{array}{r}0.738 * * * \\
(0.0238)\end{array}$ & $\begin{array}{c}0.744 * * * \\
(0.0215)\end{array}$ & $\begin{array}{r}0.744 * * * \\
(0.0186)\end{array}$ \\
\hline On-call contract & $\begin{array}{l}0.958 * * * \\
(0.0212)\end{array}$ & $\begin{array}{l}0.866 * * * \\
(0.0225)\end{array}$ & $\begin{array}{l}0.718 * * * \\
(0.0262)\end{array}$ & $\begin{array}{l}1.519 * * * \\
(0.0320)\end{array}$ & $\begin{array}{l}1.508 * * * \\
(0.0293)\end{array}$ & $\begin{array}{l}1.437 * * * \\
(0.0258)\end{array}$ \\
\hline Duration_1 & $\begin{array}{c}-0.000068 * * * \\
(6.29 \mathrm{e}-06)\end{array}$ & $\begin{array}{c}-0.000047^{* * *} \\
(6.31 \mathrm{e}-06)\end{array}$ & $\begin{array}{l}0.0000005 \\
(6.37 \mathrm{e}-06)\end{array}$ & $\begin{array}{c}-0.000644 * * * \\
(2.03 \mathrm{e}-05)\end{array}$ & $\begin{array}{c}-0.000575 * * * \\
(1.74 \mathrm{e}-05)\end{array}$ & $\begin{array}{c}-0.000469 * * * \\
(1.37 \mathrm{e}-05)\end{array}$ \\
\hline Part time coefte_1 & $\begin{array}{l}0.00780 \\
(0.0243)\end{array}$ & $\begin{array}{l}-0.0443^{*} \\
(0.0256)\end{array}$ & $\begin{array}{c}-0.274^{* * *} \\
(0.0278)\end{array}$ & $\begin{array}{c}0.709 * * * \\
(0.0429)\end{array}$ & $\begin{array}{c}0.677^{* * *} \\
(0.0391)\end{array}$ & $\begin{array}{c}0.699 * * * \\
(0.0342)\end{array}$ \\
\hline Historical use of UB & $\begin{array}{c}-1.106 * * * \\
(0.0396)\end{array}$ & $\begin{array}{c}-1.175^{* * *} \\
(0.0423)\end{array}$ & $\begin{array}{c}-1.420 * * * \\
(0.0511)\end{array}$ & $\begin{array}{c}-0.337 * * * \\
(0.0573)\end{array}$ & $\begin{array}{c}-0.386 * * * \\
(0.0529)\end{array}$ & $\begin{array}{c}-0.410^{* * *} \\
(0.0462)\end{array}$ \\
\hline
\end{tabular}


Table 9, continued

\begin{tabular}{|c|c|c|c|c|c|c|}
\hline & Stable 60 days & Stable 90 days & Stable 180 & Unstable 60 & Unstable 90 & Unstable 180 \\
\hline Number of individuals & 124,486 & 124,486 & 124,486 & 124,486 & 124,486 & 124,486 \\
\hline Number of exits & 60,492 & 52,111 & 36,674 & 33,316 & 41,697 & 57,134 \\
\hline Total number of spells & 158,363 & 158,363 & 158,363 & 158,363 & 158,363 & 158,363 \\
\hline Log Likelihood & $-671,729$ & $-145,054$ & $-113,160$ & $-671,729$ & $-145,054$ & $-113,160$ \\
\hline \multicolumn{2}{|c|}{ Implied mass point distribution } & 1 & 2 & 3 & $\mathrm{E}[\mathrm{V}]$ & \\
\hline & Probability & $1 \%$ & $23 \%$ & $76 \%$ & & \\
\hline \multirow[t]{4}{*}{60 days } & V stable & 3.31 & 0.68 & -0.24 & 0 & \\
\hline & V unstable & 0.54 & 1.69 & -0.51 & 0 & \\
\hline & Rho= & 0.83 & & & & \\
\hline & Probability & $1 \%$ & $23 \%$ & $76 \%$ & & \\
\hline \multirow[t]{3}{*}{180 days } & V stable & 3.46 & 0.05 & -0.07 & 0 & \\
\hline & V unstable & 0.24 & 1.51 & -0.45 & 0 & \\
\hline & Rho $=$ & 0.16 & & & & \\
\hline
\end{tabular}

Note: See Table 4.

Table 10: Estimation results of models with independent competing risks with shared frailty terms with inverse Gaussian distributions; 2005 and 2009 samples.

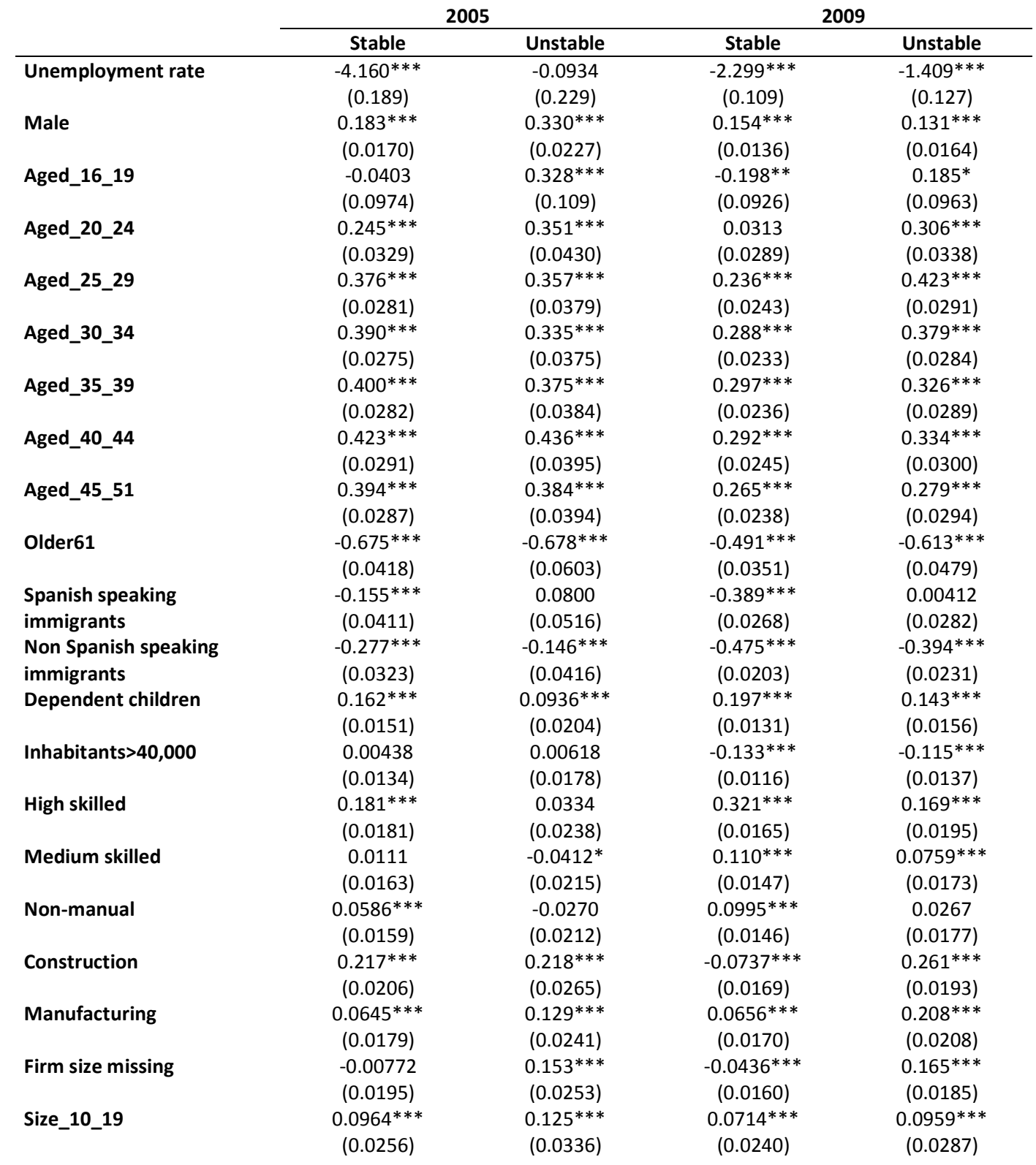


Table 10, continued

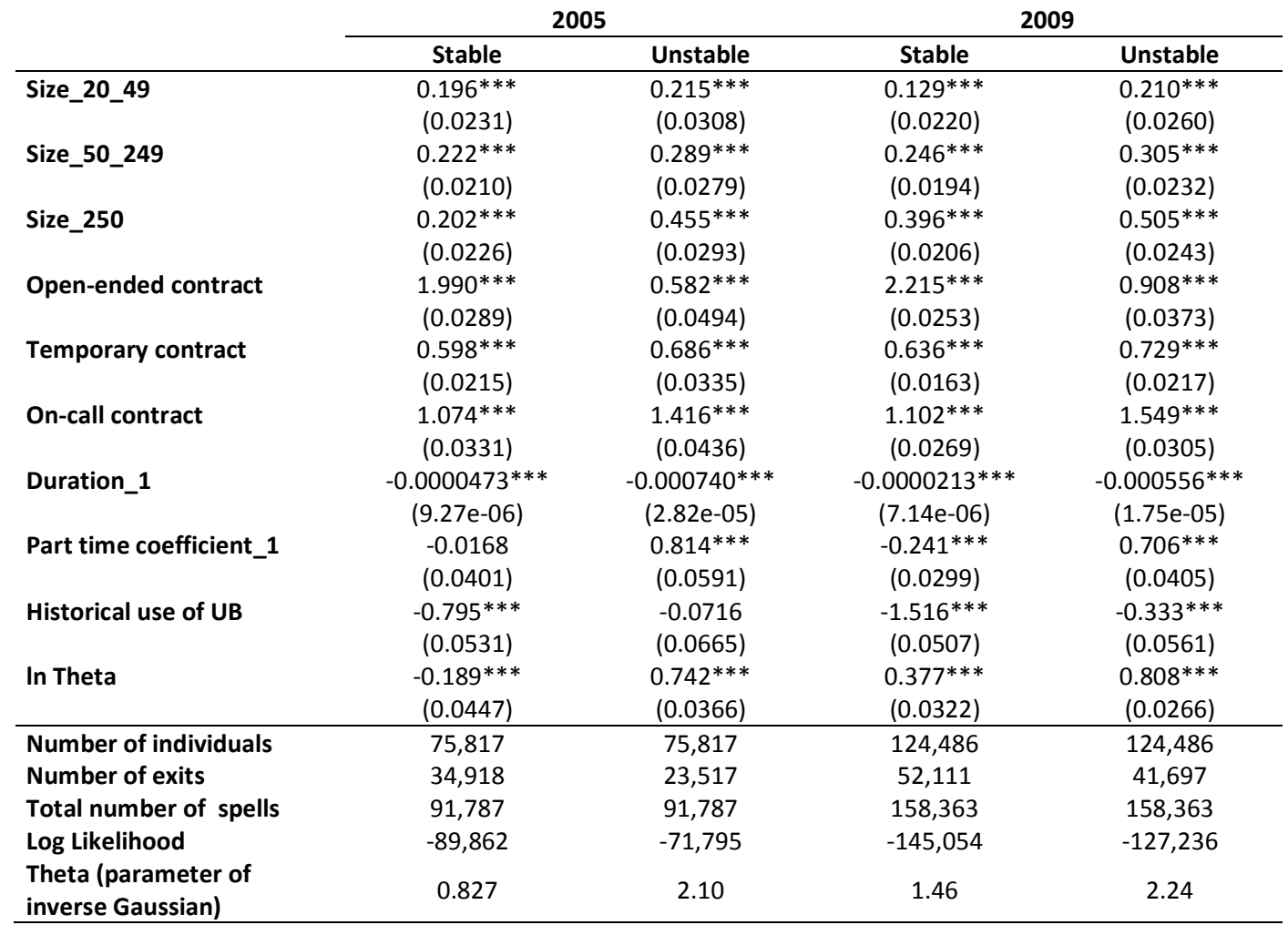

Note: See Table 4 for reference categories.

\section{References}

Alba A (1998) How temporary is temporary employment in Spain? Journal of Labor Research 19(4): 695710.

Alba A, Arranz JM, Muñoz-Bullón F (2012) Re-employment probabilities of unemployment benefit recipients. Applied Economics 44(28): 3645-3664.

Arranz JM, García-Serrano C (2011) Are the MCVL tax data useful? Ideas for mining. Hacienda Pública Española 199(4): 151-186.

Arranz JM, García-Serrano C, Toharia L (2010) The influence of temporary employment on unemployment exits in a competing risks framework. Journal of Labor Research 31(1): 67-90.

Arranz JM, Muñoz-Bullón F (2013) Unemployment benefits and recall jobs in Spain: a split population model. Working Paper IIEEF Series 4: 1-33.

Arranz JM, Muro J (2004) Recurrent unemployment, welfare benefits and heterogeneity. International Review of Applied Economics 18(4): 423-441.

Arulampalam W, Stewart M (1995) The Determinants of individual unemployment duration in an era of high unemployment. Economic Journal 105(429): 321-332.

Bentolila S, Dolado JJ (1994) Labor flexibility and wages, lessons from Spain. Economic Policy 9 (18): $54-$ 99.

Bijwaard, GE (2014) Unobserved heterogeneity in Multiple-Spell Multiple-States Duration Models, Demographic Research, forthcoming. 
Bijwaard, GE, Wahba J (2014), Do High-Income or Low-Income Immigrants Leave Faster? Journal of Development Economics, 108 (May): 54-68.

Blanchard O, Diamond P (1994) Ranking, unemployment duration, and wages. Review of Economic Studies, 61(3): 417-434.

Boockmann B, Steffes S (2005) Individual and Plant-level Determinants of Job Durations in Germany, ZEW Discussion Paper 05-89, ZEW, Mannheim.

Bover O, Arellano M, Bentolila S (2002) Unemployment duration, benefit duration and the business cycle. Economic Journal 112(479): 223-265.

Bover O, Gómez R (2004) Another Look at unemployment duration: Exit to a permanent vs. a temporary job. Investigaciones Economicas 33(2): 285-314.

Cockx B, Picchio M (2012) Are short-lived Jobs stepping stones to long-lasting Jobs? Oxford Bulletin of Economics and Statistics 84(5): 646-675.

Durán A (2007) La muestra continua de vidas laborales de la seguridad social. Revista del Ministerio de Trabajo y Asuntos Sociales 2007 (1): 231-40.

Dynarski M, Sheffrin SM (1990) The behaviour of unemployment duration over the cycle. Review of Economics and Statistics 72(2): 350-356.

Folmer H, van Dijk J (1988) Differences in unemployment duration: a regional or a personal problem? Applied Economics 20(9): 1233-1251.

García-Pérez JI (2008) La Muestra Continua de Vidas laborales (MCVL): una guía de uso para el análisis de transiciones. Revista de Economía Aplicada 16(E-1): 5-28.

García-Pérez JI, Muñoz-Bullón F (2011) Transitions into permanent employment in Spain: an empirical analysis for young workers. British Journal of Industrial Relations 49(1): 103-143.

García-Serrano C (2004) Temporary employment, working conditions and expected exits from firms. Labour 18(2): 293-316.

Heckman J, Singer B (1984) The identifiability of the proportional hazard model. Review of Economic Studies 51(2): 231-241.

Imbens G, Lynch L (2006) Re-employment probabilities over the business cycle, Portuguese Economic Journal 5(2): 111-134.

Jenkins S, Garcia-Serrano C (2004) The relationship between unemployment benefits and re-employment probabilities: Evidence from Spain. Oxford Bulletin of Economics and Statistics 66(2): 239-260.

Jimeno JF, Toharia L (1993) The effects of fixed-term employment on wages: theory and evidence from Spain. Investigaciones Economicas, Fundación SEPI 17(3): 475-494.

Kalbfleisch JD, Prentice RL (2002) The statistical analysis of failure time data. Second Edition. New York: Wiley.

Kalwij A (2010) Unemployment durations and the pattern of duration dependence over the business cycle of British males. Empirical Economics 38(2): 429-456. 
Lapuerta I (2010) Claves para el trabajo con la Muestra Continua de Vidas laborales. DemoSoc Working Paper 37 Universitat Pompeu Fabra.

Lockwood B (1991) Information Externalities in the Labour Market and the Duration of Unemployment. Review of Economic Studies 58(4): 733-753.

Lynch LM (1989) The youth labor market in the eighties: determinants of re-employment probabilities for young men and women. Review of Economics and Statistics 71(1): 37-45.

Meyer B (1990) Unemployment insurance and unemployment spells. Econometrica 58 (4): 757-782.

Narendranathan W, Nickell S (1985) Modelling the process of job search. Journal of Econometrics 28(1): 29-49.

Nickell, S (1979) Estimating the Probability of Leaving Unemployment. Econometrica 47(5): 1249-1266.

Solon G (1985) Work incentive effects of taxing unemployment benefits. Econometrica 53(2): 295-306.

Rebollo-Sanz Y (2012) Unemployment insurance and job turnover in Spain. Labour Economics 19(3): 403426.

Toharia L, Arranz JM, García-Serrano C, Herranz V (2010) El sistema de protección por desempleo y la salida del paro. Papeles de Economía Española 124: 230-246.

Toharia L, Cebrián I (2007) La temporalidad en el empleo: atrapamiento y trayectorias. Ministerio de Trabajo y Asuntos Sociales, Colección Informes y Estudios (Serie Empleo), Madrid.

Toharia L, Malo MA (2009) ¿Qué se puede esperar de las reformas del mercado de trabajo? Circunstancia № 20, 1-29. Instituto Universitario de Investigación Ortega y Gasset.

Van den Berg, GJ (2001) Duration models: Specification, identification, and multiple duration. In J. Heckman and E Leamer (Eds.), Handbook of Econometrics, Vol. V. Amsterdam: North-Holland, pp. 3381-3460. 